\title{
The Twin Crises: The Causes of Banking and Balance-of-Payments Problems
}

\author{
By Graciela L. Kaminsky and CARMEn M. Reinhart**
}

\begin{abstract}
In the wake of the Mexican and Asian currency turmoil, the subject of financial crises has come to the forefront of academic and policy discussions. This paper analyzes the links between banking and currency crises. We find that: problems in the banking sector typically precede a currency crisis-the currency crisis deepens the banking crisis, activating a vicious spiral; financial liberalization often precedes banking crises. The anatomy of these episodes suggests that crises occur as the economy enters a recession, following a prolonged boom in economic activity that was fueled by credit, capital inflows, and accompanied by an overvalued currency. (JEL F30, F41)
\end{abstract}

Pervasive currency turmoil, particularly in Latin America in the late 1970's and early 1980's, gave impetus to a flourishing literature on balance-of-payments crises. As stressed in Paul Krugman's (1979) seminal paper, in this literature, crises occur because a country finances its fiscal deficit by printing money to the extent that excessive credit growth leads to the eventual collapse of the fixed exchange-rate regime. With calmer currency markets in the mid- and late 1980's, interest in this literature languished. The collapse of the European Exchange Rate Mechanism, the Mexican peso crisis, and the wave of currency crises sweeping

\footnotetext{
* Kaminsky: Department of Economics, George Washington University, Washington, DC 20052; Reinhart: School of Public Affairs and Department of Economics, University of Maryland, College Park, MD 20742, and the National Bureau of Economic Research. We thank two anonymous referees for very helpful suggestions. We also thank Guillermo Calvo, Rudiger Dornbusch, Peter Montiel, Vincent Reinhart, John Rogers, Andrew Rose, and seminar participants at Banco de México, the Board of Governors of the Federal Reserve System, Florida State University, Harvard University, the International Monetary Fund, Johns Hopkins University, Massachusetts Institute of Technology, Stanford University, the State University of New YorkAlbany, the University of California-Berkeley, UCLA, the University of California-Santa Cruz, the University of Maryland, the University of Washington, the World Bank, and the conference on "Speculative Attacks in the Era of the Global Economy: Theory, Evidence, and Policy Implications" (Washington, DC, December 1995) for very helpful comments, and Greg Belzer, Kris Dickson, and Noah Williams for superb research assistance.
}

through Asia have, however, rekindled interest in the topic. Yet, the focus of this recent literature has shifted. While the earlier literature emphasized the inconsistency between fiscal and monetary policies and the exchange-rate commitment, the new one stresses self-fulfilling expectations and herding behavior in international capital markets. ${ }^{1}$ In this view, as Calvo (1995 p. 1) summarizes: "If investors deem you unworthy, no funds will be forthcoming and, thus, unworthy you will be."

Whatever the causes of currency crises, neither the old literature nor the new models of self-fulfilling crises have paid much attention to the interaction between banking and currency problems, despite the fact that many of the countries that have had currency crises have also had full-fledged domestic banking crises around the same time. Notable exceptions are: Carlos F. Díaz-Alejandro (1985), Andres Velasco (1987), Calvo (1995), Ilan Goldfajn and Rodrigo O. Valdés (1995), and Victoria Miller (1995). As to the empirical evidence on the potential links between what we dub the twin crises, the literature has been entirely silent. The Thai, Indonesian, and Korean crises are not the first examples of dual currency and banking woes; they are only the recent additions to a long list of casualties which includes Chile, Finland, Mexico, Norway, and Sweden.

\footnotetext{
${ }^{1}$ See Maurice Obstfeld $(1994,1995)$ and Guillermo A. Calvo (1995).
} 
In this paper, we aim to fill this void in the literature and examine currency and banking crises episodes for a number of industrial and developing countries. The former include: Denmark, Finland, Norway, Spain, and Sweden. The latter focus on: Argentina, Bolivia, Brazil, Chile, Colombia, Indonesia, Israel, Malaysia, Mexico, Peru, the Philippines, Thailand, Turkey, Uruguay, and Venezuela. The period covered spans the 1970's through 1995. This sample gives us the opportunity to study 76 currency crises and 26 banking crises. Out of sample, we examine the twin crises in Asia of 1997.

Charles Kindelberger (1978 p. 14), in studying financial crises, observes: "For historians each event is unique. Economics, however, maintains that forces in society and nature behave in repetitive ways. History is particular; economics is general." Like Kindelberger, we are interested in finding the underlying common patterns associated with financial crises. To study the nature of crises, we construct a chronology of events in the banking and external sectors. From this timetable, we draw inference about the possible causal patterns among banking and balance-of-payments problems and financial liberalization. We also examine the behavior of macroeconomic indicators that have been stressed in the theoretical literature around crisis periods, much along the lines of Barry Eichengreen et al. (1996b). Our aim is to gauge whether the two crises share a common macroeconomic background. This methodology also allows us to assess the fragility of economies around the time of the financial crises and sheds light on the extent to which the crises were predictable. Our main results can be summarized as follows.

First, with regard to the linkages among the crises, our analysis shows no apparent link between balance-of-payments and banking crises during the 1970's, when financial markets were highly regulated. In the 1980 's, following the liberalization of financial markets across many parts of the world, banking and currency crises become closely entwined. Most often, the beginning of banking-sector problems predate the balance-of-payment crisis; indeed, knowing that a banking crisis was underway helps predict a future currency crisis. The causal link, nevertheless, is not unidirectional. Our results show that the collapse of the currency deepens the banking crisis, activating a vicious spiral. We find that the peak of the banking crisis most often comes after the currency crash, suggesting that existing problems were aggravated or new ones created by the high interest rates required to defend the exchange-rate peg or the foreignexchange exposure of banks.

Second, while banking crises often precede balance-of-payments crises, they are not necessarily the immediate cause of currency crises, even in the cases where a frail banking sector puts the nail in the coffin of what was already a defunct fixed exchange-rate system. Our results point to common causes, and whether the currency or banking problems surface first is a matter of circumstance. Both crises are preceded by recessions or, at least, below normal economic growth, in part attributed to a worsening of the terms of trade, an overvalued exchange rate, and the rising cost of credit; exports are particularly hard hit. In both types of crises, a shock to financial institutions (possibly financial liberalization and/or increased access to international capital markets) fuels the boom phase of the cycle by providing access to financing. The financial vulnerability of the economy increases as the unbacked liabilities of the banking-system climb to lofty levels.

Third, our results show that crises (external or domestic) are typically preceded by a multitude of weak and deteriorating economic fundamentals. While speculative attacks can and do occur as market sentiment shifts and, possibly, herding behavior takes over (crises tend to be bunched together), the incidence of crises where the economic fundamentals were sound are rare.

Fourth, when we compared the episodes in which currency and banking crises occurred jointly to those in which the currency or banking crisis occurred in isolation, we find that for the twin crises, economic fundamentals tended to be worse, the economies were considerably more frail, and the crises (both banking and currency) were far more severe.

The rest of the paper is organized as follows. The next section provides a chronology of the crises and their links. Section II reviews the stylized facts around the periods surrounding the crises, while Section III addresses the issues of the vulnerability of economies around the time of the crisis and the issue of predictability. The final section discusses the findings and possibilities for future research. 


\section{The Links Between Banking and Currency Crises}

This section briefly discusses what the theoretical literature offers as explanations of the possible links between the two crises. The theoretical models also guide our choice of the financial and economic indicators used in the analysis.

\section{A. The Links: Theory}

A variety of theoretical models have been put forth to explain the linkages between currency and banking crises. One chain of causation, stressed in James Stoker (1994), runs from balance-of-payments problems to banking crisis. An initial external shock, such as an increase in foreign interest rates, coupled with a commitment to a fixed parity, will result in the loss of reserves. If not sterilized, this will lead to a credit crunch, increased bankruptcies, and financial crisis. Moreover, Frederic S. Mishkin (1996) argues that, if a devaluation occurs, the position of banks could be weakened further if a large share of their liabilities is denominated in a foreign currency. Models, such as Velasco (1987), point to the opposite causal directionfinancial-sector problems give rise to the currency collapse. Such models stress that when central banks finance the bailout of troubled financial institutions by printing money, we return to the classical story of a currency crash prompted by excessive money creation.

A third family of models contend that currency and banking crises have common causes. An example of this may be found in the dynamics of an exchange-rate-based inflation stabilization plan, such as that of Mexico in 1987. Theory and evidence suggest that such plans have well-defined dynamics ${ }^{2}$ : Because inflation converges to international levels only gradually, there is a marked cumulative real exchange-rate appreciation. Also, at the early stages of the plan there is a boom in imports and economic activity, financed by borrowing abroad. As the current account deficit continues to widen, financial markets become convinced that the sta-

\footnotetext{
${ }^{2}$ See Reinhart and Carlos A. Végh (1996) for a review of this literature and the empirical regularities.
}

bilization program is unsustainable, fueling an attack against the domestic currency. Since the boom is usually financed by a surge in bank credit, as banks borrow abroad, when the capital inflows become outflows and asset markets crash, the banking system caves in. Ronald I. McKinnon and Huw Pill (1996) model how financial liberalization together with microeconomic distortions-such as implicit deposit insurance-can make these boom-bust cycles even more pronounced by fueling the lending boom that leads to the eventual collapse of the banking system. Goldfajn and Valdés (1995) show how changes in international interest rates and capital inflows are amplified by the intermediating role of banks and how such swings may also produce an exaggerated business cycle that ends in bank runs and financial and currency crashes.

So, while theory does not provide an unambiguous answer as to what the causal links between currency and banking crises are, the models are clear as to what economic indicators should provide insights about the underlying causes of the twin crises. High on that list are international reserves, a measure of excess money balances, domestic and foreign interest rates, and other external shocks, such as the terms of trade. The inflation stabilizationfinancial liberalization models also stress the boom-bust patterns in imports, output, capital flows, bank credit, and asset prices. Some of these models also highlight overvaluation of the currency, leading to the underperformance of exports. The possibility of bank runs suggests bank deposits as an indicator of impending crises. Finally, as in Krugman (1979), currency crises can be the by-product of government budget deficits.

\section{B. The Links: Preliminary Evidence}

To examine these links empirically, we first need to identify the dates of currency and banking crises. In what follows, we begin by describing how our indices of financial crises are constructed.

Definitions, Dates, and Incidence of Crises. -Most often, balance-of-payments crises are resolved through a devaluation of the domestic currency or the floatation of the exchange rate. 
But central banks can and, on occasion, do resort to contractionary monetary policy and foreign-exchange market intervention to fight the speculative attack. In these latter cases, currency market turbulence will be reflected in steep increases in domestic interest rates and massive losses of foreign-exchange reserves. Hence, an index of currency crises should capture these different manifestations of speculative attacks. In the spirit of Eichengreen et al. (1996a, b), we constructed an index of currency market turbulence as a weighted average of exchange-rate changes and reserve changes. ${ }^{3}$

With regard to banking crises, our analysis stresses events. The main reason for following this approach has to do with the lack of highfrequency data that capture when a financial crisis is under way. If the beginning of a banking crisis is marked by bank runs and withdrawals, then changes in bank deposits could be used to date the crises. Often, the banking problems do not arise from the liability side, but from a protracted deterioration in asset quality, be it from a collapse in real-estate prices or increased bankruptcies in the nonfinancial sector. In this case, changes in asset prices or a large increase in bankruptcies or nonperforming loans could be used to mark the onset of the crisis. For some of the earlier crises in emerging markets, however, stock-market data is not available. ${ }^{4}$ Indicators of business failures and nonperforming loans are also usually available only at low frequencies, if at all; the latter are also made less informative by banks' desire to hide their problems for as long as possible.

Given these data limitations, we mark the beginning of a banking crisis by two types of events: (1) bank runs that lead to the closure, merging, or takeover by the public sector of one or more financial institutions (as in Venezuela in 1993); and (2) if there are no runs, the closure, merging, takeover, or large-scale government assistance of an important financial

\footnotetext{
${ }^{3}$ The construction of the index is described in the Data Appendix. The dates of the crises appear in Appendix Table A1, and the level of the index and key events around the crises dates are reported in the working paper version of this paper (Kaminsky and Reinhart, 1996).

${ }^{4}$ Bank stocks could be an indicator, but in many of the developing countries an important share of the banks are not traded publicly.
}

institution (or group of institutions) that marks the start of a string of similar outcomes for other financial institutions (as in Thailand in 19961997). We rely on existing studies of banking crises and on the financial press; according to these studies the fragility of the banking sector was widespread during these periods. This approach to dating the beginning of the banking crises is not without drawbacks. It could date the crises too late, because the financial problems usually begin well before a bank is finally closed or merged; it could also date the crises too early, because the worst of crisis may come later. To address this issue we also date when the banking crisis hits its peak, defined as the period with the heaviest government intervention and/or bank closures.

Our sample consists of 20 countries for the period 1970-mid-1995. The countries are those listed in the introduction and Appendix Tables A1 and A2. We selected countries on the multiple criteria of being small open economies, with a fixed exchange rate, crawling peg, or band through portions of the sample; data availability also guided our choices. This period encompasses 26 banking crises and 76 currency crises.

As to the incidence of the crises (Table 1 and Figure 1), there are distinct patterns across decades. During the 1970's we observe a total of 26 currency crises, yet banking crises were rare during that period, with only three taking place. The absence of banking crises may reflect the highly regulated nature of financial markets during the bulk of the 1970's. By contrast, while the number of currency crises per year does not increase much during the 1980's and 1990's (from an average of 2.60 per annum to 3.13 per annum, Table 1, first row), the number of banking crises per year more than quadruples in the post-liberalization period. Thus, as the second row of Table 1 highlights, the twin crisis phenomenon is one of the 1980's and 1990's.

Figure 1 also shows that financial crises were heavily bunched in the early 1980's, when real interest rates in the United States were at their highest level since the 1930's. This may suggest that external factors, such as interest rates in the United States, matter a great deal as argued in Calvo et al. (1993). Indeed, Jeffrey Frankel and Andrew K. Rose (1996) find that foreign interest rates play a significant role in predicting 
TABle 1-Frequency of Crises Over Time

\begin{tabular}{|c|c|c|c|c|c|c|}
\hline \multirow[b]{3}{*}{ Type of crisis } & \multicolumn{6}{|c|}{ Number of crises } \\
\hline & \multicolumn{2}{|c|}{ 1970-1995 } & \multicolumn{2}{|c|}{ 1970-1979 } & \multicolumn{2}{|c|}{ 1980-1995 } \\
\hline & Total & $\begin{array}{l}\text { Average } \\
\text { per year }\end{array}$ & Total & $\begin{array}{l}\text { Average } \\
\text { per year }\end{array}$ & Total & $\begin{array}{l}\text { Average } \\
\text { per year }\end{array}$ \\
\hline Balance-of-payments & 76 & 2.92 & 26 & 2.60 & 50 & 3.13 \\
\hline Twin & 19 & 0.73 & 1 & 0.10 & 18 & 1.13 \\
\hline Single & 57 & 2.19 & 25 & 2.50 & 32 & 2.00 \\
\hline Banking & 26 & 1.00 & 3 & 0.30 & 23 & 1.44 \\
\hline
\end{tabular}

Note: Episodes in which the beginning of a banking crisis is followed by a balance-of-payments crisis within 48 months are classified as twin crises.

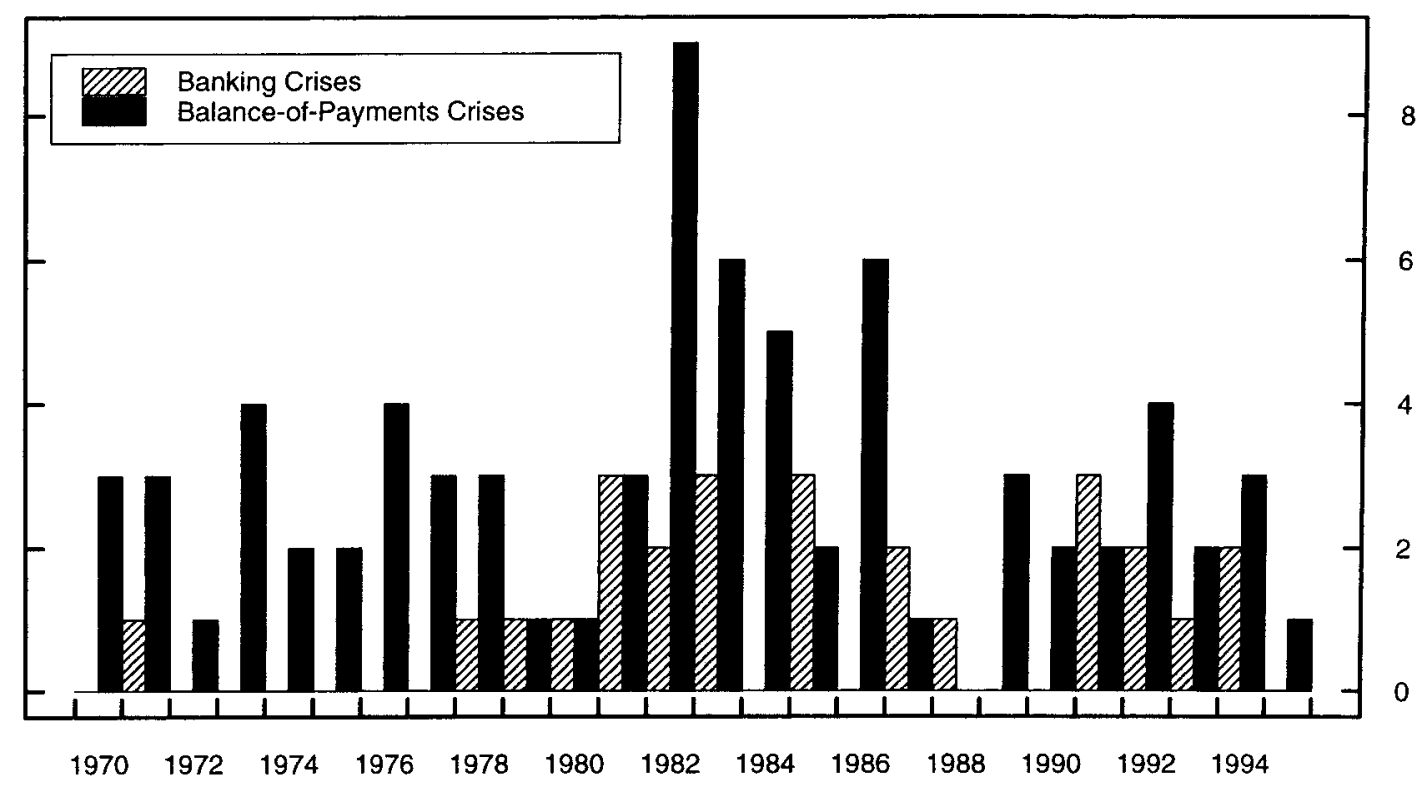

Figure 1. Number of Crises Per Year

currency crashes. A second explanation why crises are bunched is that contagion effects may be present, creating a domino effect among those countries that have anything less than immaculate fundamentals. Sara Calvo and Reinhart (1996) present evidence of contagion in capital flows to Latin American countries while Eichengreen et al. (1996a) find evidence that knowing there is a crisis elsewhere increases the probability of a domestic currency crisis.

Table 2 provides the dates of financial liberalization, the beginning and peak of the banking crisis, and the date of the balance-of-payments crisis that was nearest to the beginning of the banking crisis. ${ }^{5}$ By selecting the nearest currency crisis, whether it predates or follows the beginning of the banking crisis, we allow the data to reveal what the temporal patterns are. The dates for the remaining crises are given in the Appendix tables.

The Twin Crises. - We next examine how the currency and banking crises are linked.

\footnotetext{
${ }^{5}$ If the peak month for the banking crisis is not known, we list the midpoint of that year as the date.
} 
Table 2-The Timing of the Twin Crises and Financial Liberalization

\begin{tabular}{|c|c|c|c|c|}
\hline \multirow[b]{2}{*}{ Country } & \multirow{2}{*}{$\begin{array}{c}\text { Financial } \\
\text { liberalization }\end{array}$} & \multicolumn{2}{|c|}{ Banking crisis } & \multirow{2}{*}{$\begin{array}{c}\text { Closest balance- } \\
\text { of-payment } \\
\text { crisis }\end{array}$} \\
\hline & & Beginning & Peak & \\
\hline \multirow[t]{3}{*}{ Argentina } & 1977 & March 1980 & July 1982 & February 1981 \\
\hline & & May 1985 & June 1989 & September 1986 \\
\hline & & December 1994 & March 1995 & February 1990 \\
\hline Bolivia & 1985 & October 1987 & June 1988 & September 1985 \\
\hline \multirow[t]{2}{*}{ Brazil } & 1975 & November 1985 & November 1985 & November 1986 \\
\hline & & December 1994 & March 1996 & October 1991 \\
\hline Chile & 1974 & September 1981 & March 1983 & August 1982 \\
\hline Colombia & 1980 & July 1982 & June 1985 & March 1983 \\
\hline Denmark & Early 1980's & March 1987 & June 1990 & August 1983 \\
\hline Finland & 1982 & September 1991 & June 1992 & November 1991 \\
\hline Indonesia & 1983 & November 1992 & November 1992 & September 1986 \\
\hline Israel & 1985 & October 1983 & June 1984 & October 1983 \\
\hline Malaysia & 1978 & July 1985 & August 1986 & July 1975 \\
\hline \multirow[t]{2}{*}{ Mexico } & 1974 & September 1982 & June 1984 & December 1982 \\
\hline & 1991 & October 1992 & March 1996 & December 1994 \\
\hline Norway & 1980 & November 1988 & October 1991 & May 1986 \\
\hline Peru & 1991 & March 1983 & April 1983 & October 1987 \\
\hline Philippines & 1980 & January 1981 & June 1985 & October 1983 \\
\hline Spain & 1974 & November 1978 & January 1983 & July 1977 \\
\hline Sweden & 1980 & November 1991 & September 1992 & November 1992 \\
\hline \multirow[t]{2}{*}{ Thailand } & 1989 & March 1979 & March 1979 & November 1978 \\
\hline & & October 1983 & June 1985 & November 1984 \\
\hline Turkey & 1980 & January 1991 & March 1991 & March 1994 \\
\hline \multirow[t]{2}{*}{ Uruguay } & $1976-1979$ & March 1971 & December 1971 & December 1971 \\
\hline & & March 1981 & June 1985 & October 1982 \\
\hline Venezuela & 1981, 1989 & October 1993 & August 1994 & May 1994 \\
\hline \multicolumn{5}{|c|}{$\begin{array}{c}\text { Memorandum item: } \\
\text { Out of sample }\end{array}$} \\
\hline Indonesia & & November 1992 & Ongoing & August 1997 \\
\hline Malaysia & & September 1997 & Ongoing & August 1997 \\
\hline Philippines & & July 1997 & Ongoing & July 1997 \\
\hline Thailand & & May 1996 & Ongoing & July 1997 \\
\hline
\end{tabular}

Note: Episodes in which the beginning of a banking crisis is followed by a balance-of-payment crisis within 48 months are classified as twin crises.

Sources: American Banker, various issues; Gerald Caprio, Jr. and Daniela Klingebiel (1996); New York Times, various issues; Sundararajan et al. (1991); Wall Street Journal, various issues.

We begin by calculating the unconditional probability of currency crises and banking crises in our sample. For instance, the probability that a currency crisis will occur in the next 24 months over the entire sample is simply 24 times 76 (the total number of currency crises in the sample) divided by the total number of monthly observations in the sample. These calculations yield unconditional probabilities for currency and banking crises, which are 29 percent and 10 percent, respectively (Table 3). The difference in the probabilities of the two kinds of crises highlights the relatively higher frequency of currency crises in the sample.

We next calculate a family of conditional probabilities. For instance, if knowing that there is a banking crisis within the past 24 months helps predict a currency crisis then the probability of a currency crisis, conditioned on information that a banking crisis is under way, should be higher than the unconditional probability of a balance-of-payments crisis. In other words, a banking crisis increases the probability that a country will fall prey to a currency crisis. This is precisely what the results summarized in Table 3 show. The probability of a currency crisis conditioned on the beginning of bankingsector problems is 46 percent, well above the unconditional estimate of 29 percent. Hence, it 
TABle 3-Probabilities of CRISES

\begin{tabular}{lc}
\hline \hline \multicolumn{2}{c}{ Probabilities of balance-of-payment crises } \\
Type & $\begin{array}{c}\text { Value } \\
\text { (in percent) }\end{array}$ \\
\hline Unconditional & 29 \\
$\begin{array}{l}\text { Conditional on the beginning of a } \\
\text { banking crisis }\end{array}$ & 46 \\
$\begin{array}{l}\text { Conditional on the peak of a banking } \\
\text { crisis }\end{array}$ & 22 \\
\hline
\end{tabular}

Probabilities of banking crises

Type

Value

(in percent)

Unconditional

10

Beginning of a banking crisis conditional on a balance-of-payments crisis

Beginning of a banking crisis conditional on financial liberalization

Peak of a banking crisis conditional on a balance-of-payments crisis

Notes: The balance-of-payment crisis windows are defined as the 24 months preceding the crisis. The banking crisis windows are defined as the 12 months before and the 12 months after the beginning (or peak) of the crises. The unconditional probabilities of balance-of-payment and banking crises are calculated as the total number of months in the respective crisis windows divided by the total number of months in the sample. The balance-of-payment probabilities conditional on a banking crisis (beginning or peak) are calculated as the number of months in the balance-ofpayment crisis windows that occur within 24 months of the banking crises (beginning or peak) divided by the total number of months in the banking crisis windows. The probabilities of banking crises conditional on balance-ofpayment crises are calculated as the number of months in the banking crisis windows that occur within 24 months of a balance-of-payment crisis divided by the total number of months in the balance-of-payment crisis windows. The probability of a banking crisis conditional on financial liberalization is calculated as the total number of months in the banking crisis windows that occur during times of financial liberalization divided by the total number of months during which the banking sector was in a regime of financial liberalization. All probabilities were estimated using the data for the 20 countries in the 1970-mid-1995 period.

could be argued, as Díaz-Alejandro (1985) and Velasco (1987) did for the Chilean crisis in the early 1980's, that, in an important number of cases, the bailout of the banking system may have contributed to the acceleration in credit creation observed prior to the currency crises (see Herminio Blanco and Peter M. Garber, 1986; Sebastian Edwards, 1989; Eichengreen et al., 1996b; and this paper). Even in the absence of a large-scale bailout, a frail banking system is likely to tie the hands of the central bank in defending the currency-witness Indonesia in August 1997.

If, instead, the peak of the banking crisis is used as the conditioning piece of information, no valuable information is gained; indeed, the conditional probability is 22 percent and below the unconditional. This result follows from the fact that a more common pattern (see Table 2) appears to be that the peak of the banking crisis comes after the currency crisis. For instance, knowing that there is a currency crisis does not help predict the onset of a banking crisis, this conditional probability is 8 percent; knowing that there was a currency crisis does help to predict the probability that the banking crisis will worsen, this conditional probability is 16 percent.

Taken together, these results seem to point to the existence of vicious circles. Financial-sector problems undermine the currency. Devaluations, in turn, aggravate the existing bankingsector problems and create new ones. These adverse feedback mechanisms are in line with those suggested by Mishkin (1996) and can be amplified, as we have seen in several of the recent Asian crises, by banks' inadequate hedging of foreign-exchange risk. The presence of vicious circles would imply that, a priori, the twin crises are more severe than currency or banking crises that occur in isolation.

To measure the severity of a currency crisis, we focus on a composite measure that averages reserve losses and the real exchange-rate depreciation. $^{6}$ For reserves, we use the six-month percent change prior to the crisis month, as reserve losses typically occur prior to the devaluation (if the attack is successful). For the real exchange rate, we use the six-month percent change following the crisis month, because large depreciations occur after, and only if, the central bank concedes by devaluing or floating the currency. This measure of severity is constructed for each currency crisis in our sample and the averages are reported in Table 4 separately for the 19 twin crises in our sample and for the others. In line with our results that the beginning of the banking crisis precedes the balance-of-payments crisis, we define the twin

\footnotetext{
${ }^{6}$ The real exchange rate is used, as high inflation countries will typically have larger nominal devaluations.
} 
TABle 4-The Severity of THE CRISES

\begin{tabular}{|c|c|c|c|c|}
\hline \multirow[b]{2}{*}{ Severity measure } & \multicolumn{2}{|c|}{ Banking crises } & \multicolumn{2}{|c|}{$\begin{array}{c}\text { Balance-of- } \\
\text { payments } \\
\text { crises }\end{array}$} \\
\hline & Twin & Single & Twin & Single \\
\hline $\begin{array}{l}\text { Cost of bailout } \\
\text { (Percent of GDP) }\end{array}$ & 13.3 & $5.1^{*}$ & NA & NA \\
\hline $\begin{array}{l}\text { Loss of reserves } \\
\text { (Percent) }\end{array}$ & NA & NA & 25.4 & $8.3^{*}$ \\
\hline $\begin{array}{l}\text { Real depreciation } \\
\text { (Percent) }\end{array}$ & NA & NA & 25.7 & 26.6 \\
\hline Composite index & NA & NA & 25.6 & 17.5 \\
\hline
\end{tabular}

Notes: Loss of reserves is the percentage change in the level of reserves in the six months preceding the crises. Real depreciation is the percentage change in the real exchange rate (with respect to the dollar for the countries that peg to the dollar and with respect to the mark for the countries that peg to mark) in the six months following the crises. The composite index is the unweighted average of the loss of reserves and real depreciation. Episodes in which the beginning of a banking crisis is followed by a balance-of-payments crisis within 48 months are classified as twin crises.

* Denotes that the measure of severity of single-crises episodes is statistically different from the twin-crises severity at the 5-percent level. An NA denotes not applicable.

crises as those episodes in which a currency crisis follows the beginning of the banking crisis within the next 48 months. For banking crises, we use the bailout costs, as a percent of GDP, as the measure of severity. As Table 4 highlights, bailout costs are significantly larger (more than double) in the twin crises than for banking crises which were not accompanied by a currency crisis. As to balance-of-payments crises, the results are mixed. Reserve losses sustained by the central bank are significantly bigger (Table 4) but the real depreciations are of comparable orders of magnitude.

Our results also yield an insight as to the links of crises with financial liberalization (Table 3). In 18 of the 26 banking crises studied here, the financial sector had been liberalized during the preceding five years, usually less. Only in a few cases in our sample countries, such as the early liberalization efforts of Brazil in 1975 and Mexico in 1974, was the liberalization not followed by financial-sector stress. In the 1980's and 1990's most liberalization episodes have been associated with financial crises of varying severity. Only in a handful of countries (for instance, Canada, which is not in the sample) did financial-sector liberalization proceed smoothly. Indeed, the probability of a banking crisis (beginning) conditional on financial liberalization having taken place is higher than the unconditional probability of a banking crisis. This suggests that the twin crises may have common origins in the deregulation of the financial system and the boom-bust cycles and asset bubbles that, all too often, accompany financial liberalization. The stylized evidence presented in Caprio and Klingebiel (1996) suggests that inadequate regulation and lack of supervision at the time of the liberalization may play a key role in explaining why deregulation and banking crises are so closely entwined.

\section{The Macroeconomic Background of the Crises}

To shed light on whether both types of crises may have common roots, we analyze the evolution of 16 macroeconomic and financial variables around the time of the crises. The variables used in the analysis were chosen in light of theoretical considerations and subject to data availability. Monthly data was used to get a clearer view (than would otherwise be revealed by lower frequency data) of developments as the crisis approaches and by the desire to evaluate to what extent these indicators were giving an early signal of impending trouble - an issue that will be taken up in the next section.

The indicators associated with financial liberalization are the $\mathrm{M} 2$ multiplier, the ratio of domestic credit to nominal GDP, the real interest rate on deposits, and the ratio of lending-todeposit interest rates. Other financial indicators include: excess real M1 balances, real commercial-bank deposits, and the ratio of M2 (converted into U.S. dollars) divided by foreign-exchange reserves (in U.S. dollars). ${ }^{7}$ The indicators linked to the current account include the percent deviation of the real exchange rate from trend, as a measure of misalignment, the value of exports and imports (in U.S. dollars), and the terms of trade. ${ }^{8}$ The

\footnotetext{
${ }^{7} \mathrm{M} 2$ to reserves captures to what extent the liabilities of the banking system are backed by international reserves. In the event of a currency crisis, individuals may rush to convert their domestic currency deposits into foreign currency, so that this ratio captures the ability of the central bank to meet those demands (Calvo and Enrique Mendoza, 1996).

${ }^{8} \mathrm{An}$ increase in the real exchange-rate index denotes a depreciation.
} 

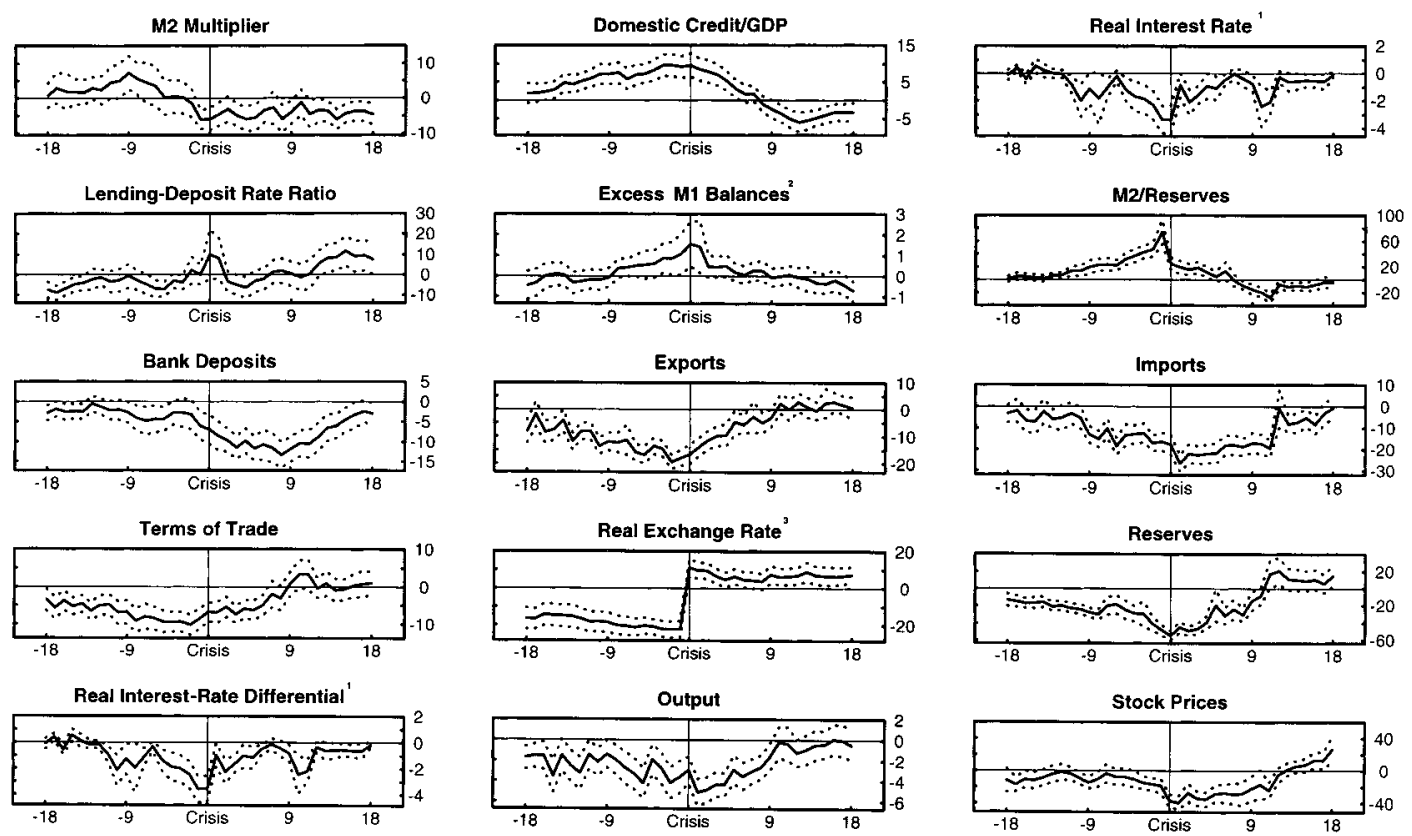

Figure 2. Empirical Regularities During Balance-of-Payments Crises

Notes: The values of the variable relative to "tranquil" times are reported on the vertical axes. The horizontal axes represent the number of months before (with a negative sign) and after the crisis. The solid line represents the average for all the crises for which data was available. The dotted lines denote plus/minus one standard error around the average. Unless otherwise noted, all variables are reported as 12-month changes, in percent, relative to "tranquil" times. 1. Monthly rates, in percentage points, relative to "tranquil" times. 2. Actual less estimated money demand. Percent deviation relative to "tranquil" times. 3. Deviations from trend, in percent, relative to "tranquil" times.

indicators associated with the capital account are: foreign-exchange reserves (in U.S. dollars) and the domestic-foreign real interest-rate differential on deposits (monthly rates in percentage points). The indicators of the real sector are industrial production and an index of equity prices (in U.S. dollars). ${ }^{9}$ Lastly, the fiscal variable is the overall budget deficit as a percent of GDP.

Of course, this is not an exhaustive list of potential indicators. In particular, political variables, such as the timing of an election, can also be linked to the timing of these crises. Indeed, the evidence presented in Deepak Mishra (1997), who examines a subset of the currency crises in this study, suggests that devaluations, more often than

\footnotetext{
${ }^{9}$ Detailed definitions of all the variables and their sources are provided in the Data Appendix.
}

not, follow elections. Indeed, an election raises the probability of a future devaluation, even after controlling for economic fundamentals.

Except for the interest-rate variables, the deviations of the real exchange rate from trend, our proxy for excess real M1 balances, and the lending/deposit interest-rate ratio, which are in levels, we focus on the 12-month percent changes of the remaining 10 variables. The pre- and postcrises behavior of all variables is compared to the average behavior during tranquil periods, which are all the remaining observations in our sample and serves as our control group.

Figures 2, 3, and 4 illustrate the behavior of the variables around the time of the balanceof-payments crises, banking crises, and twin crises, respectively; each panel portrays a different variable. The horizontal axis records the number of months before and after the beginning of the crises; the vertical axis 

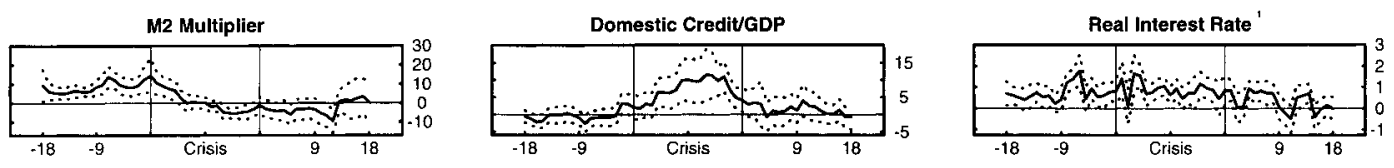

Lending-Deposit Rate Ratio
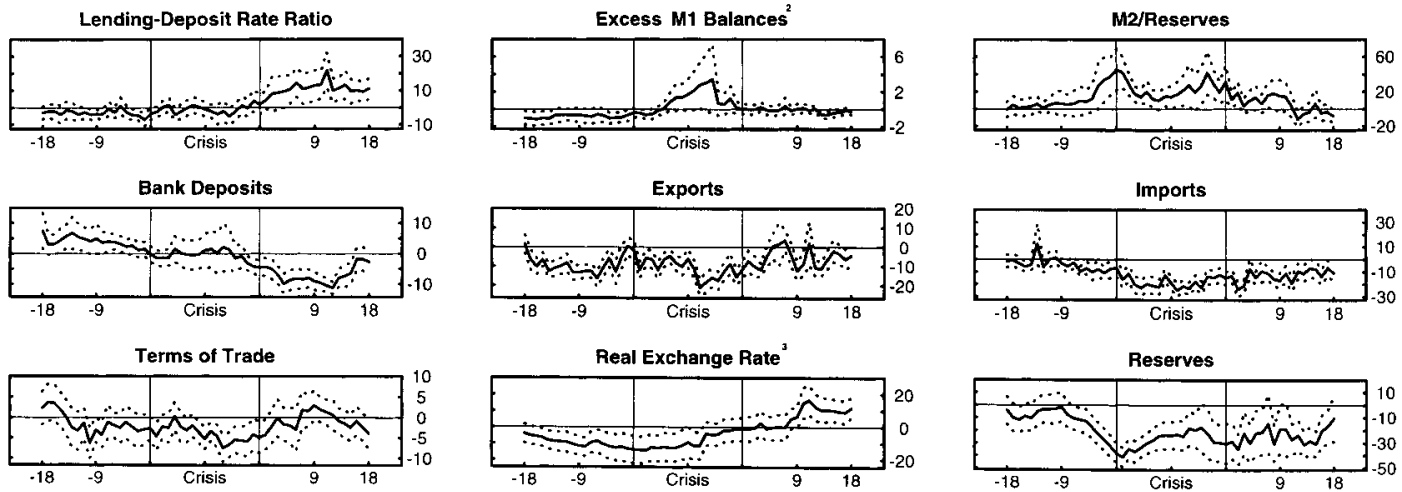

Real Interest-Rate Differential'
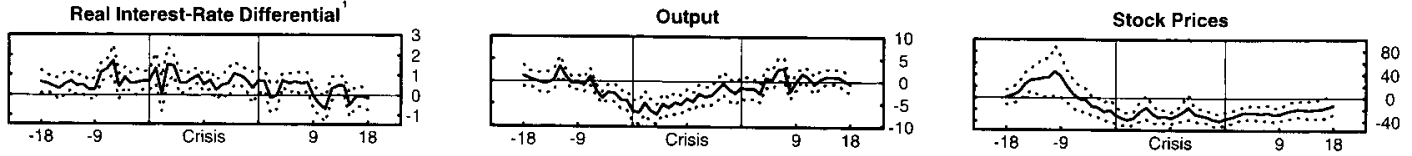

Figure 3. Empirical Regularities During Banking CRises

Notes: The values of the variable relative to "tranquil" times are reported on the vertical axes. The horizontal axes represent the number of months before (with a negative sign) and after the crisis. The solid line represents the average for all the crises for which data was available. The dotted lines denote plus/minus one standard error around the average. Unless otherwise noted, all variables are reported as 12-month changes, in percent, relative to "tranquil" times. 1. Monthly rates, in percentage points, relative to "tranquil" times. 2. Actual less estimated money demand. Percent deviation relative to "tranquil" times. 3. Deviations from trend, in percent, relative to "tranquil" times.

records the percent difference (percentagepoint difference for interest rates) between tranquil and crisis periods. In all the figures the solid line represents the average for all the crises for which data was available. ${ }^{10}$ Hence, if no data points are missing, the solid line represents the average behavior of that indicator during the months around 76 currency crises and 26 banking crises. For Figures 2 and 3 , the dotted lines denote plus/minus one standard error around the average. For example, the top center panel of Figure 2 shows that, on average, the 12-month growth in the domestic credit/GDP ratio is about 15 percent higher than in tranquil times. In Figure 4 the

\footnotetext{
${ }^{10}$ See Appendix Tables A1 and A2 for a detailed indication of any missing data around crisis dates.
}

solid line shows the evolution of the indicators for the twin-crises episodes while the dashed line denotes the averages for the currency crises that were not accompanied by a banking crisis.

For currency crises we focus on the 18month period before and after the crisis. Unlike balance-of-payments crises, in which reserves are lost abruptly and currency pegs abandoned, banking crises are protracted affairs which tend to come in waves and, hence, the depth of the crisis is seldom reached at the first sign of outbreak (see Table 2). For this reason, we widen the window and focus on the 18 months before the onset of the crisis, an 18-month arbitrarily chosen crisis period, and the 18-month post-crisis period. At any rate, because most of our analysis focuses on the causes leading up to the crises, our main results will not be affected whether the crises 

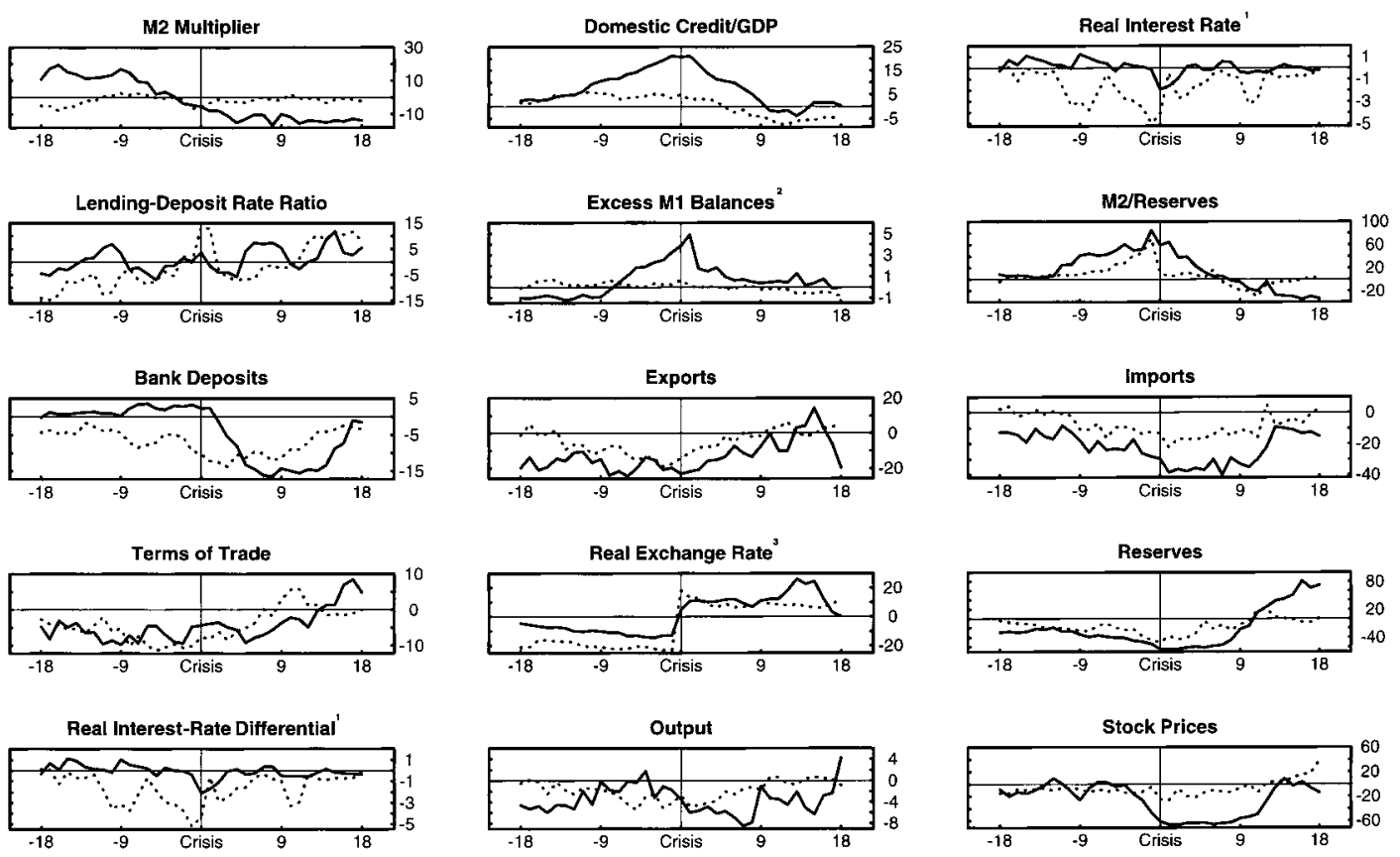

Figure 4. Empirical Regularities During Twin Crises

Notes: The values of the variables relative to "tranquil" times are reported on the vertical axes. The horizontal axes represent the number of months before (with a negative sign) and after a crisis. The solid lines show the behavior during twin-crises episodes, and the dotted lines show the behavior during "single"-crises episodes. Unless otherwise noted, all variables are reported as 12-month changes, in percent, relative to "tranquil" times. 1. Monthly rates, in percentage points, relative to "tranquil" times. 2. Actual less estimated money demand. Percent deviation relative to "tranquil" times. 3. Deviations from trend, in percent, relative to "tranquil" times.

lasted less or more than a year. For the 19 episodes of the twin crises, we focus on the 18 months prior to the balance-of-payments crisis. Given that banking crises usually predate currency crises in our sample, this implies we are already looking at a period of heavy financial-sector stress.

\section{A. The Financial Sector}

Until the 1970's, most financial markets were regulated with rationed credit and, often, negative real interest rates. The late 1970's and beginning of the 1980's, however, witnessed sweeping financial reforms both in developed and emerging markets, which led to, among other things, increases in real interest rates. ${ }^{11}$ Because financial liberalization often precedes

\footnotetext{
${ }^{11}$ See Vincente Galbis (1993).
}

banking crises - the indicators associated with financial liberalization presented in the first four panels of Figures 2, 3, and 4 (from left to right) merit scrutiny. The growth in the M2 multiplier rises steadily up to nine months prior to the currency crisis and the onset of the banking crisis; indeed, for banking crises the multiplier grows at above normal rate in the entire 18 months prior to the crisis. The draconian reductions in reserve requirements that often accompany financial liberalization play a role in explaining the large increases in the M2 multiplier. Yet the rise in the multiplier prior to currency crises is entirely accounted for by its evolution ahead of the twin crises, as shown in Figure 4.

The growth in domestic credit/GDP remains above normal as the balance-ofpayments crisis nears (Figure 2) but particularly accelerating markedly as the twin crises approaches; throughout this period it remains 
well above the growth rates recorded for tranquil periods, consistent with a credit boom (and bust) story. This ratio also rises in the early phase of the banking crisis. It may be that, as the crisis unfolds, the central bank may be pumping money to the banks to alleviate their financial situation or the evolution of the denominator has changed. While credit is rapidly expanding 18 to 6 months before the crisis, the economy is still in a vigorous expansion phase (see below), with healthy GDP growth. The leveraging of households and business becomes evident as the economy slips into recession. The real interest rate evolves very differently ahead of balance-of-payments and banking crises. For currency crises, interest rates bounce around in the range of 0 to 2 percentage points per month below the average during periods of tranquility-this may reflect lax monetary policy ahead of the currency crisis or simply the fact that 26 of the currency crises are in the 1970's, when interest rates were regulated and not particularly informative. By contrast, prior to banking crises and, therefore, twin crises (which are almost exclusively in the post-liberalization part of the sample), real interest rates are 1 to 2 percentage points higher (at a monthly rate) than in tranquil times in the pre-crisis period. The above normal real interest rates may have a variety of causes: These could be the product of a recent financial liberalization; high real rates could also reflect increased risk taking by banks; ${ }^{12}$ they could be the product of a tight monetary policy stance. Real interest rates do not return to their levels in tranquil times as the crisis deepens, perhaps reflecting that banks may respond to deposit withdrawals by keeping deposit interest rates high. The lending-deposit rate ratio hovers around its level in tranquil times up until about six months prior to the balance-ofpayments crises and then begins to climb; by the time of the crisis it is about 10 percent higher than in tranquil times, possibly reflecting a deterioration in credit risk. For banking crises, the lending/ deposit ratio remains close to normal levels in the pre-crisis period. Only at around the peak of the banking crises does the lending/deposit ratio increase above its level in tranquil times, as banks become increasingly unwilling to lend.

The next three panels show the evolution of the

\footnotetext{
${ }^{12}$ See V. Sundararajan and Tomas Baliño (1991).
}

monetary indicators. The middle panel in the second row of Figures 2 and 3 show the excess MI balances. The periods prior to the currency and banking crises are characterized by an excess supply of real M1 balances; the excess liquidity is particularly pronounced for the twin-crises episodes, which nearly account for all the abovenormal behavior ahead of currency crises. Without overinterpreting this result, given the shortcomings of money-demand estimation, the picture that emerges is consistent with the deficit financing as in the Krugman (1979) framework or the excess liquidity may be created to ease conditions for troubled financial institutions. In any case, at some point the excess liquidity becomes incompatible with maintaining the exchange-rate commitment - and a currency crisis emerges. This would suggest that the high real interest rates prior to banking crises were due to factors other than monetary policy. The next panel shows the evolution of the 12-month change in M2/reserves of central banks. For both currency and banking crises, this ratio grows well above its norm prior to the crises. The increases are associated with both a vigorous expansion in M2 (witness the multiplier) and a sharp decline in foreign currency reserves (discussed below). As Calvo and Mendoza (1996) do for Mexico 1994, we find that the M2/reserves ratio over the 76 currency crises indicates an abrupt decrease in the backing ratio in the months preceding the crisis. Indeed, the growth rate is 70 percent in excess of the tranquil period average, highlighting vulnerability of the system. This observation is equally descriptive of both single-currency and twin-crises episodes. The growth rate of bank deposits remains close to normal during the 18 months prior to the financial crises, but the loss of deposits accelerates as the crises unfold. There may be multiple reasons for this sudden decline. Past financial-crises periods have often been characterized by massive and persistent capital flight. Deposits only start to recover a year and a half after the onset of the financial crises.

\section{B. The External Sector}

The next four panels of Figures 2, 3, and 4 present indicators associated with the current account. The middle panel of the third row in each figure chronicles the abysmal performance of the growth of exports in the year and a half 
preceding the currency and banking crisesexports consistently underperform (relative to normal times) during this period. By the time a balance-of-payments crisis is under way, export growth is about 20 percent below (annual rate) the average growth observed in tranquil periods. Once the appreciation is reversed, export performance improves sharply, outdoing the performance observed during tranquil periods about nine months after the crisis began. Export performance is particularly poor during the twin-crises episodes. The behavior of import growth is more difficult to justify on the basis of relative price developments (see below). Import growth remains close to the norm during tranquil periods up to about nine months before a currency crisis and then declines; for banking crises, we see the tail end of the import boom and the subsequent slide prior to the crisis. During this pre-crisis period, income and relative price effects are moving in opposite directions, and the observed decline in import growth may well be accounted for by the slowdown in economic activity (see below) during that time. Import growth remains below that of normal periods throughout the post-crisis period.

The next panel provides evidence on the terms of trade. Crises are preceded, on average, by a deterioration of the terms of trade, with an annual decline that is about 10 percent deeper than those observed in tranquil times prior to a balance-of-payments crisis. This persistent adverse performance of the terms of trade erodes purchasing power and may also account for the weakness in imports in the months preceding the crisis. This weakness is equally evident in single- and twincrises episodes. For banking crises, up to about a year prior to the crisis, terms-of-trade shocks appear to have been positive-perhaps helping to explain the earlier boom (see below); as the crisis nears we see some evidence of adverse terms-of-trade shocks. The middle panel in the fourth row shows the evolution of real exchange rates. During the year before the balance-of-payments and banking crises (as stressed in Rudiger Dornbusch et al., 1996), the real exchange rate shows evidence of being overvalued, relative to its average level during tranquil times. In periods preceding the currency crash, it is appreciating relative to its trend (an overvaluation of about 20 percent relative to tranquil periods). The real exchange-rate appreciation does reverse itself rapidly with the devaluation, suggesting that productivity shocks or preference changes were unlikely to account for the initial appreciation. Exchange-rate-based inflation stabilization plans have often given rise to large cumulative real exchange-rate appreciations, as domestic inflation fails to converge to international levels. As noted in Reinhart and Végh (1996) and Kaminsky and Leonardo Leiderman (1998), many of those plans ended in a balance-of-payments crisis. Following the crash, the real exchange rate depreciates substantially (and is about 10 percent higher than in tranquil times). Over time, higher domestic inflation erodes in part the improvement in competitiveness.

In the absence of monthly data on capital flows for most of the period and most of the countries in our sample, we extract information about capital account developments by focusing on the indicators shown in the next two panels. As expected, the 12-month percentage change in foreign-exchange reserves of the central banks falls substantially in the months prior to both banking and balance-of-payments crises. The loss of reserves is particularly steep and longer lived following the crises for the 19 twin-crises episodes. As early as 12 months prior to the balance-of-payments crisis, reserve growth is about 20 percent below that observed during tranquil periods; although we report 12month changes, which introduce positive serial correlation in the data, reserves do not decrease continuously. There are modest short-lived reversals in the path followed by reserves, which suggest that the central banks may have had spells in which they fought the reserve loss with contractionary monetary policy (note that there are brief spells where real interest rates rise prior to the crisis - see the third panel) before finally conceding defeat and devaluing. Following the devaluation (or flotation), foreign-exchange reserves of central banks start to increase again.

Finally, the first panel in the bottom row shows the evolution of the domestic-foreign real interest-rate differential on deposits. Interest differentials do not reflect increasing expectations of a devaluation as the currency crisis nears. Turning to banking crises, the picture that 
emerges is quite distinct from its counterpart in Figure 2; while in balance-of-payments crises interest-rate differentials were not appreciably different from tranquil periods prior to crises, differentials in the case of banking crises remain above those observed in periods of tranquility. One explanation for this difference among the two crises has to do with the bunching of the banking crises in the post-financial liberalization period.

\section{The Real Sector}

The last two panels in the figures show the evolution of output growth and changes in stock prices. The deterioration of the terms of trade, the overvaluation of the currency, and the weakening export performance are reflected in a marked slowing in economic activity and a decline in output prior to both crises. For balanceof-payments crises, the 12-month growth in output bounces in a range of 2 to 6 percent below the comparable growth rates during tranquil periods-with a tendency for the recession to deepen as the crisis nears. Interestingly, and in line with the greater severity of the twin crises, the combination of currency and banking problems appears to take a more devastating toll on the real economy as the recession is far deeper and longer than the recessions associated with currency crashes alone. At growth rates which are 8 percent below those observed in tranquil periods, the twin-crisis recession is twice as severe. As Kindelberger (1978) observes: "Financial crises are associated with the peaks in business cycles ... the financial crisis is a culmination of a period of economic expansion that leads to downturn." While in the 18 months prior to a balance-of-payments crisis there is no evidence of a residual economic boom, that is not the case in the pre-bankingcrisis period. As Figure 3 shows, up to about 8 months before the banking crises the economy was recording growth rates above those observed during tranquil periods. Yet, the real exchange-rate appreciation that characterizes pre-crisis periods is often cited as a key factor behind the squeeze in profit margins that eventually leads to increased bankruptcies, a rise in nonperforming loans, a deepening in the economic contraction, and banking-sector problems.
The last panel shows the evolution of stock prices. During the 18 months prior to a balanceof-payments crisis, the equity market steadily underperforms (relative to tranquil times) - at first, not by much, but as the crisis nears, changes in stock prices (that is, stock returns [in dollars]) are about 40 percent below those observed in noncrisis periods. The weakening in equity prices is, most likely, reflecting both the deteriorating cyclical position of the economy, reduced foreign demand as capital inflows are reversed, and the worsening balance sheets of firms, as the overvaluation takes its toll. The crash is particularly severe when currency and banking crises nearly coincide (Figure 4). Unlike the onset of a banking crisis (see below), the equity market was already past it cyclical peak well before the crisis begins. On the eve of banking crises, the return on equity prices up to about nine months prior to the crises suggests a boom (relative to tranquil periods) which may (or may not) be an asset-price bubble. During the boom phase, returns exceed those of noncrises periods by about 40 percent on an annual basis. The beginning of the recession is also reflected in the stock market, which collapses the year before the crisis; this collapse is also apparent in other asset markets, most notably real estate. ${ }^{13}$

Finally, although not shown in the figures, the fiscal deficit/GDP ratio is higher in the two years prior to the currency crisis and one year prior to the banking crisis. While the bigger deficit could stem from higher government spending, the weakness in output prior to crises could lead to a shortfall in revenues.

\section{The Anatomy of Crises}

In what follows, we offer an alternative approach to examine the evolving nature of the

\footnotetext{
${ }^{13}$ For example, in the boom period leading up to the 1981 Argentine banking crisis, stock returns (in U.S. dollars) were as high as 813 percent during the 12 months ending May 1979; by May 1981, the 12-month capital loss was 60 percent. The crash in asset values is cited in most case studies as an important factor contributing to the problems of the banks. Also, due to either mismanagement or outright fraud, in many of the crises in our sample a substantial portion of banks and finance companies were considerably overexposed to real estate.
} 
crises, pinpoint their origin, and gauge their probability conditioned on signals from one or more indicators. The methodology used, while not previously applied to analyze currency and banking crises, has a long history in the rich literature that evaluates the ability of macroeconomic and financial time series to predict business-cycle turning points. ${ }^{14}$ The remainder of this section is divided into two parts, the first describes the statistical methodology used, while the second applies that methodology to the 102 currency and banking crises that make up our sample.

\section{A. Methodology}

To examine the causes of crises, gauge the vulnerability of the economy on the eve of crisis, and assess whether the crisis itself could be forecasted by anomalous economic developments, we need to make four sets of judgments: First, we must have a well-defined notion of what is classified as a crisis. Second, we must agree on a list of variables that are potential leading indicators. Third, we need to decide upon a criteria that allows us to classify the behavior of an indicator as either a signal of a crisis or normal (no signal). Last, if an indicator is giving a signal, we have to determine if a crisis happens within a reasonable period of time or if the signal was a false alarm. Hence, we also need to define what is considered to be a reasonable period of time. Section I deals with the definition and dating of banking and currency crises, while the previous section and the Data Appendix discuss the indicators. In this subsection, we describe the approach used to define what is a signal and what is a reasonable period of time.

The Interval Between Signals and Crisis: Defining a Reasonable Period of Time.-In what follows, the maximum interval of time between the signal and the crisis was decided a priori as 24 months in the case of balance-of-payments crises. ${ }^{15}$ Hence, any signal given within the 24-month period before the beginning of the

\footnotetext{
${ }^{14}$ See, for instance, Francis Diebold and Glen Rudebusch (1989), James H. Stock and Mark W. Watson (1989), and Reinhart and Vincent R. Reinhart (1996).

${ }^{15}$ An 18- and 12-month window were also used; the results are available from the authors.
}

crisis is labeled a good signal; any other signal outside that 24-month window is labeled a false alarm or noise. For banking crises, any signal given within the 12-month period before the beginning of the crisis or within 12 months following the beginning of the crisis is labeled a good signal. The two different signaling windows for currency and banking crises have to do with the different timing of the peaks of both crises, as previously discussed. In addition, the events that mark the beginning of a banking crisis are often not seen as systemic at the time and are not treated by policy makers as harbingers of a crisis. Since symptoms of a crisis are sometimes evident well before the crises erupt, the narrower windows (say, 12-month) were thought to penalize indicators (such as M2/reserves) that tend to give an early warning.

The Threshold: Defining a Signal.-In Section II we noted that the crises were preceded by marked declines in equity returns. Yet, surely, not every decline in equity returns presages a crisis. Hence, we need to select an appropriate threshold or cutoff that separates when a decline in equity returns is considered a signal of a crisis and when it is not. As is the case of selecting the size of the rejection region in hypothesis testing, choosing the optimal threshold involves a trade-off. Suppose that our null hypothesis is that we are in a tranquil state of nature and (for a particular country) we are weighing whether to arbitrarily set the threshold for annual equity returns at minus 15 percent or at minus 40 percent. Suppose further, that for this country 10 percent of the observations posted annual equity returns below minus 15 percent, but only 3 percent of the observations showed equity returns below minus 40 percent. Our aim is to use the readings for this indicator to test the null hypothesis that we are in a tranquil state of nature. If we choose the minus 15 percent threshold, the size of $\alpha$ (the rejection region) is 10 percent-this is the probability of rejecting the null hypothesis when it is true (Type I error). In this case, the threshold may be too lax-it is likely to catch all the crises but it is also likely to generate a lot of false alarms. Instead, we could adopt the minus 40 percent threshold, which cuts the size of $\alpha$ to 3 percent; this reduces the probability of Type I error at the expense of increasing the probability of Type II 
error (not rejecting the null hypothesis when it is false). With this tight threshold we may miss all but the most severe of the crises-the price of reducing the number of false alarms is accurately calling a lower proportion of crises.

We select the threshold value on an indicatorby-indicator basis, by performing a fine grid search over a broad range of critical regions up to a maximum of 30 percent. For each threshold value in our grid search we compute the noiseto-signal ratio. ${ }^{16} \mathrm{We}$ then select the threshold value that minimizes the noise-to-signal ratio. As to the location of the rejection region, whether it is the upper or lower tail of the frequency distribution for each indicator, we rely on the theory as a guide. The threshold values for the 16 indicators, as well as the location of the rejection region and its theoretical justification, are given in Table 5. For example, for currency and banking crises large output declines signal a crisis, so a $<$ sign in Table 5 denotes that the rejection region is located at the bottom tail of the distribution.

This criterion does have drawbacks which are worth mentioning. First, if an indicator gives an early signal and policy makers heed the signal and preempt a crisis, that signal is labeled as false and the indicator is penalized with an unduly high noise-tosignal ratio. In addition, a signal within the window is treated the same irrespective of whether it was

\footnotetext{
${ }^{16}$ The definition of noise-to-signal ratio used throughout is best illustrated by considering the following two-by-two matrix:
}

\begin{tabular}{lcc}
\hline \hline & $\begin{array}{c}\text { Crisis occurs } \\
\text { in the } \\
\text { following 24 } \\
\text { months }\end{array}$ & $\begin{array}{c}\text { No crisis occurs } \\
\text { in the following } \\
24 \text { months }\end{array}$ \\
\hline $\begin{array}{c}\text { Indicator issues a } \\
\text { signal }\end{array}$ & $A$ & $B$ \\
$\begin{array}{c}\text { Indicator does not } \\
\text { issue a signal }\end{array}$ & $C$ & $D$ \\
\hline
\end{tabular}

If a variable signals and a crisis occurs in the following 24 months (counted in cell $A$ ) the signal is considered accurate. If a variable signals and no crisis occurs in that time frame (counted in cell $B$ ), the signal is said to be a false alarm or noise. Hence, a perfect indicator would only have entries in cells $A$ and $D$. More generally, the noise-to-signal ratio for any indicator is given by the number of entries in $[B /(B+$ $D)] /[A /(A+C)]$. Hence, it is the ratio of false signals to all possible bad signals divided by the ratio of good signals to all possible good signals. An extremely noisy indicator would have few entries in $A$ and $D$, many in $B$ and $C$. given 12 months before the crisis erupts or only the month before. Naturally, from the vantage point of the policy maker the earlier signal is the more valuable one.

\section{B. The Anatomy of Crises}

The methodology just described was applied to the 16 indicators and 102 crises in the sample and the four recent Asian crises out of sample.

Appendix Tables A1 and A2 show the results on a crisis-by-crisis and indicator-by-indicator basis. An NA denotes some or all the observations were missing during the pre-crisis 24-month window; a 1 denotes at least one signal was given during the 24-month window, and a zero indicates no signals were issued. Hence, for example, column (12) in Appendix Table A1 scores the performance of foreign-exchange reserves; there are four NA entries, hence we have full data for this indicator for 72 balance-of-payments crises. In 75 percent of the crises [row (1) Summary Statistics, bottom of the table] there were one or more signals during the 24 months prior to the crisis. The last column (17) lists what proportion (in percent) of the indicators were sending signals. Data availability permitting, the tables also show the evolution of the indicators out of sample for the Asian crises of 1997.

About the Origins of Crises. - Table 6 summarizes the results in Appendix Tables A1 and A2. The indicators are shown individually and are also grouped into sectors along the lines described in the previous section: financial liberalization, other financial, current account, capital account, realside, and fiscal. For balance-of-payments crises, we also examine subsamples before financial liberalization, which encompasses the 1970's, and after financial liberalization, as well as those currency crises which occurred alongside a banking crises. The latter appear under the column labelled Twin. As nearly all banking crises fall in the post-liberalization period, no subsamples for these are reported. Table 6 presents the percentage of crises accurately called by each indicator. As to the various groups we also report the simple arithmetic average of the proportion of crises accurately called by all the indicators in that subgroup. Capital account indicators accurately called the highest proportion of balance-of-payments crises 
Table 5-Threshold Values for Signaling CRises

\begin{tabular}{|c|c|c|c|}
\hline \multirow[b]{2}{*}{ Indicators } & \multicolumn{2}{|c|}{$\begin{array}{l}\text { Threshold values and } \\
\text { the location of the } \\
\text { critical region } \\
\end{array}$} & \multirow[b]{2}{*}{ Comments } \\
\hline & $\begin{array}{l}\text { Balance-of- } \\
\text { payment } \\
\text { crises }\end{array}$ & $\begin{array}{c}\text { Banking } \\
\text { crises }\end{array}$ & \\
\hline \multicolumn{4}{|l|}{ Financial sector } \\
\hline \multicolumn{4}{|l|}{ Financial liberalization } \\
\hline M2 multiplier & $>0.86$ & $>0.90$ & \multirow{2}{*}{$\begin{array}{l}\text { Both banking and currency crises have been linked to rapid growth } \\
\text { (boom-bust) in credit and the monetary aggregates (see McKinnon } \\
\text { and Pill, 1996). }\end{array}$} \\
\hline Domestic credit/GDP & $>0.90$ & $>0.95$ & \\
\hline Real interest rate & $>0.88$ & $>0.80$ & \multirow[b]{2}{*}{$\begin{array}{l}\text { For banking crises, the choice is unambiguous since financial } \\
\text { deregulation is associated with high interest rates (which could reflect } \\
\text { increased risk taking [see Galbis, 1993]). A liquidity crunch (say to } \\
\text { defend a peg) will also hurt banks. For balance-of-payments crises it } \\
\text { is less clear-cut; higher real interest rates could reflect a higher risk } \\
\text { premia and fears of devaluation. Yet, using the lower interest rates } \\
\text { for signals could be justified for balance-of-payments crises on the } \\
\text { basis of loose monetary policy. An increase in the lending/deposit } \\
\text { ratio can capture a decline in loan quality. }\end{array}$} \\
\hline $\begin{array}{l}\text { Lending-deposit rate } \\
\text { ratio }\end{array}$ & $>0.80$ & $>0.87$ & \\
\hline \multicolumn{4}{|r|}{ 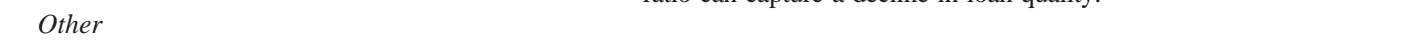 } \\
\hline Excess M1 balances & $>0.94$ & $>0.91$ & \multirow{3}{*}{$\begin{array}{l}\text { This is a "loose" monetary policy story (see Krugman, 1979). } \\
\text { For the motivation on M2/reserves, see Calvo and Mendoza (1996). } \\
\text { Capital flight and a run against the domestic banks may precede } \\
\text { both currency and banking crises (see Goldfajn and Valdes, 1995). }\end{array}$} \\
\hline M2/reserves & $>0.87$ & $>0.90$ & \\
\hline Bank deposits & $<0.10$ & $<0.16$ & \\
\hline \multicolumn{4}{|r|}{ 空 } \\
\hline \multicolumn{4}{|l|}{ Current account } \\
\hline Exports & $<0.10$ & $<0.10$ & \multirow{3}{*}{$\begin{array}{l}\text { Real exchange-rate overvaluations and a weak external sector are a } \\
\text { part of a currency crisis. It adds vulnerability of the banking } \\
\text { sector, since a loss of competitiveness and external markets could } \\
\text { lead to recession, business failures, and a decline in the quality of } \\
\text { loans. Thus, large negative shocks to exports, the terms of trade, } \\
\text { and the real exchange rate are associated with signals (see } \\
\text { Dornbush et al., 1995). }\end{array}$} \\
\hline Terms of trade & $<0.16$ & $<0.19$ & \\
\hline Real exchange rate & $<0.10$ & $<0.10$ & \\
\hline Imports & $>0.90$ & $>0.80$ & $\begin{array}{l}\text { Theory is ambiguous as to where we should locate the rejection } \\
\text { region. Rapid import growth could be the sign of a buoyant } \\
\text { economy (this would argue for a negative shock to imports); it } \\
\text { could also be the sign of overvaluation. Hence a positive shock to } \\
\text { imports could be a signal. Both possibilities were explored. }\end{array}$ \\
\hline \multicolumn{4}{|r|}{ 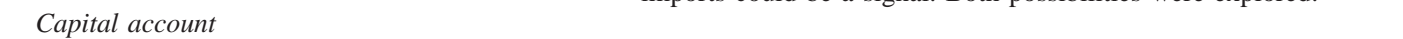 } \\
\hline Reserves & $<0.15$ & $<0.28$ & \multirow[t]{2}{*}{ See discussion under bank deposits and real interest rates. } \\
\hline $\begin{array}{c}\text { Real interest-rate } \\
\text { differential }\end{array}$ & $<0.89$ & $>0.81$ & \\
\hline \multicolumn{4}{|l|}{ Real sector } \\
\hline Output & $<0.11$ & $<0.14$ & \multirow{2}{*}{$\begin{array}{l}\text { Recessions and the burst of asset price bubbles precede financial } \\
\text { crises (see Gary Gorton, 1988; Charles W. Calomiris and Gorton, } \\
\text { 1991). }\end{array}$} \\
\hline Stock prices & $<0.11$ & $<0.10$ & \\
\hline \multicolumn{4}{|r|}{ 然 } \\
\hline Deficit/GDP & $>0.86$ & $>0.86$ & $\begin{array}{l}\text { Loose fiscal policy financed by credit from the central bank (see } \\
\text { Krugman, 1979). }\end{array}$ \\
\hline
\end{tabular}

Note: The definitions and sources of the indicators are described in the Data Appendix.

(about 81 percent). Financial liberalization indicators were next in line, accurately signaling 74 percent of the currency crises before they occurred; for the twin crises their performance is even better. Among the capital account and financial indicators that fared the worst are bank deposits, the lending-deposit ratio, and excess M1 balances. Current account indicators followed 
Table 6-The Onset of Financial Crises: Early Signals

\begin{tabular}{|c|c|c|c|c|c|c|}
\hline \multirow[b]{3}{*}{ Indicators } & \multicolumn{6}{|c|}{ Percent of crises accurately called } \\
\hline & \multicolumn{5}{|c|}{ Balance-of-payment crises } & \multirow[b]{2}{*}{$\begin{array}{c}\text { Banking } \\
\text { crises }\end{array}$} \\
\hline & Total & Single & Twin & $\begin{array}{c}\text { Before } \\
\text { financial } \\
\text { liberalization }\end{array}$ & $\begin{array}{c}\text { After } \\
\text { financial } \\
\text { liberalization }\end{array}$ & \\
\hline Financial sector & 67 & 67 & 67 & 67 & 68 & 65 \\
\hline Financial liberalization & 74 & 72 & 78 & 64 & 77 & 71 \\
\hline M2 multiplier & 76 & 75 & 78 & 74 & 77 & 73 \\
\hline Domestic credit/GDP & 61 & 59 & 67 & 56 & 65 & 50 \\
\hline Real interest rate & 89 & 86 & 94 & 78 & 91 & 100 \\
\hline Lending-deposit rate ratio & 71 & 70 & 73 & 50 & 73 & 57 \\
\hline Other & 57 & 58 & 53 & 57 & 56 & 57 \\
\hline Excess M1 balances & 37 & 43 & 22 & 52 & 26 & 32 \\
\hline M2/reserves & 81 & 79 & 89 & 74 & 86 & 75 \\
\hline Bank deposits & 51 & 52 & 47 & 44 & 56 & 67 \\
\hline External sector & 72 & 71 & 74 & 72 & 72 & 82 \\
\hline Current account & 68 & 67 & 70 & 70 & 66 & 75 \\
\hline Exports & 85 & 83 & 89 & 78 & 89 & 88 \\
\hline Terms of trade & 75 & 72 & 83 & 73 & 77 & 96 \\
\hline Real exchange rate & 59 & 57 & 67 & 58 & 60 & 58 \\
\hline Imports & 52 & 57 & 39 & 73 & 40 & 60 \\
\hline Capital account & 81 & 80 & 83 & 74 & 83 & 96 \\
\hline Reserves & 75 & 74 & 79 & 70 & 78 & 92 \\
\hline Real interest-rate differential & 86 & 86 & 88 & 78 & 89 & 100 \\
\hline Real sector & 69 & 69 & 70 & 61 & 72 & 85 \\
\hline Output & 74 & 73 & 77 & 68 & 76 & 89 \\
\hline Stock prices & 64 & 65 & 63 & 53 & 68 & 81 \\
\hline Fiscal sector & 28 & 27 & 29 & 21 & 31 & 44 \\
\hline
\end{tabular}

Notes: Episodes in which the beginning of a banking crisis is followed by a balance-of-payments crisis within 48 months are classified as twin crises. An indicator is said to have accurately called a crisis if it issues at least one signal in the crisis window on the basis of the criterion shown in Table 5. For each indicator, each cell in the table represents the number of times that indicator correctly calls a crisis as a percentage of the total number of crises. For the different sectors, each cell represents the simple average of the percentage of crises accurately called by all the individual variables in that group.

next (68 percent accurately called) but this is largely owing to the weak performance of imports in accurately calling crises; exports, the terms of trade, and the real exchange rate do much better. The fiscal variable fared the worst, accurately calling only slightly over a quarter of the currency crises.

One key difference between banking and currency crises, highlighted in Table 6 , is the role of the real sector, which appears to be considerably more important for banking crises-giving early signals in 85 percent of the crises. ${ }^{17}$ Indeed, output and stock prices signaled in 89 and 81 percent, respectively, of the banking crises for which data for these indicators

\footnotetext{
${ }^{17}$ For a discussion of the evolving nature of crises see the working paper, Kaminsky and Reinhart (1996).
}

was available. As much of the literature on banking crises stresses, particularly asymmetric information models (see Calomiris and Gorton, 1991), the evidence presented here suggests that the bursting of asset-price bubbles and increased bankruptcies associated with an economic downturn appear to be closely linked to domestic financial problems.

Yet another feature that is revealed in Table 6 is that the proportion of crises accurately called rises for 13 out of the 16 indicators when singlecurrency crises are compared to their twin counterparts. The improved performance of most of the indicators is not entirely surprising, in light of the greater severity of the twin-crises episodes.

Fragility on the Eve of Crises.-Table 7 presents strong evidence that, for both banking and currency crises, multiple economic problems 
Table 7-Economic Fragility on the Eve of CRISES

\begin{tabular}{|c|c|c|c|c|c|c|}
\hline \multirow[b]{3}{*}{$\begin{array}{l}\text { Number of indicators } \\
\text { signaling a crisis } \\
\text { (in percent) }\end{array}$} & \multicolumn{6}{|c|}{ Number of crises (in percent) } \\
\hline & \multicolumn{5}{|c|}{ Balance-of-payments crises } & \multirow[b]{2}{*}{$\begin{array}{c}\text { Banking } \\
\text { crises }\end{array}$} \\
\hline & Total & Single & Twin & $\begin{array}{c}\text { Before } \\
\text { financial } \\
\text { liberalization }\end{array}$ & $\begin{array}{c}\text { After } \\
\text { financial } \\
\text { liberalization }\end{array}$ & \\
\hline $80-100$ & 26.7 & 28.6 & 21.1 & 40.0 & 17.8 & 30.8 \\
\hline $60-79$ & 45.3 & 41.1 & 57.9 & 23.3 & 60.0 & 53.8 \\
\hline $40-59$ & 20.0 & 21.4 & 15.8 & 20.0 & 20.0 & 11.5 \\
\hline $20-39$ & 6.7 & 8.9 & 0.0 & 13.3 & 2.2 & 3.9 \\
\hline Less than 20 & 1.3 & 0.0 & 5.3 & 3.3 & 0.0 & 0.0 \\
\hline
\end{tabular}

Notes: This table captures the state of distress of the economy in different crisis episodes. Each cell represents the proportion of crises with a given proportion of signals. For example, 21.1 percent of the twin balance-of-payment crises had 80-100 percent of indicators signaling a crisis. Episodes in which the beginning of a banking crisis is followed by a balance-ofpayments crisis within 48 months are classified as twin crises.

were simultaneously building. We construct a measure of the fragility of the economy in the 24 months preceding the crisis by tallying on a crisis-by-crisis basis what proportion of the indicators were signaling during that period. ${ }^{18}$ Hence, if 14 of the 16 indicators are sending a signal prior to the crisis, this crisis would be counted in the first row of Table 7, labeled 80 percent to 100 percent. It appears that crises are not simply a story of an overvalued exchange rate or too rapid a monetary expansion. In about 30 percent of the currency crises, 80 percent or more of the indicators were sending signals. The economies appear to be particularly frail on the eve of twin crises, with a higher proportion of the indicators signaling. Indeed, in about 80 percent of the twin crises, at least 60 percent of the indicators were sending a signal. There were basically no banking crises with less than 20 percent of the indicators signaling. For further evidence of the diversity of the economic problems on the eve of crises on a crisis-by-crisis basis, see Appendix Tables A1 and A2. The finding that when the balance-of-payments crises occur jointly with a banking crisis (under the heading Twin, Table 7) economies appear to have more widespread problems perhaps is not entirely surprising, given the earlier results which suggest the twin crises tend to be more severe.

These results would appear to suggest that the

\footnotetext{
${ }^{18}$ These are reported for each crisis in column (17) of the Appendix tables.
}

overwhelming majority of crises, external or domestic, have a multitude of weak economic fundamentals at their core. While speculative attacks do occur as market sentiment shifts and, possibly, herding behavior takes over, such self-fulfilling crises appear to be quite rare. Indeed, in the context of the Exchange Rate Mechanism crises this issue has been the subject of much debate. ${ }^{19}$ Not only are the signals many, but their sources are multiple, as shown in Table 7-with the financial sector external (capital account) and domestic playing a key role.

\section{Final Remarks}

We have examined the empirical regularities and the sources and scope of problems in the onset of 76 currency crises and 26 banking crises. We find that banking and currency crises are closely linked in the aftermath of financial liberalization, with banking crises, in general, beginning before the currency collapse. We also find evidence of vicious cycles, in which the currency collapse further undermines an already ailing banking sector. When currency and banking crises occur jointly, they are far more severe than when they occur in isolation. In both types of crises, a financial shock, possibly financial liberalization or increased access to international capital markets, appears to activate a boom-bust cycle by providing easy access to financing. Finally, in both crises we find a

\footnotetext{
${ }^{19}$ See Eichengreen et al. (1996a).
} 
Table A1-Anatomy of Balance-of-Payments CRises ${ }^{\mathrm{a}}$

\begin{tabular}{|c|c|c|c|c|c|c|c|c|}
\hline Country & Crisis & $\begin{array}{c}\mathrm{M} 2 \\
\text { multiplier } \\
(1)\end{array}$ & $\begin{array}{c}\text { Domestic } \\
\text { credit/GDP } \\
(2)\end{array}$ & $\begin{array}{l}\text { Real } \\
\text { interest } \\
\text { rate } \\
(3) \\
\end{array}$ & $\begin{array}{l}\text { Lending- } \\
\text { deposit } \\
\text { rate ratio } \\
\text { (4) }\end{array}$ & $\begin{array}{c}\text { Excess } \\
\text { M1 } \\
\text { balances } \\
(5) \\
\end{array}$ & $\begin{array}{c}\mathrm{M} 2 / \\
\text { reserves } \\
(6)\end{array}$ & $\begin{array}{c}\text { Bank } \\
\text { deposits } \\
(7)\end{array}$ \\
\hline \multirow[t]{7}{*}{ Argentina } & June 70 & NA & NA & NA & NA & 1 & NA & NA \\
\hline & June 75 & 0 & 1 & NA & NA & 1 & 1 & 0 \\
\hline & Feb. 81 & 1 & 0 & 1 & NA & 0 & 1 & 0 \\
\hline & July 82 & 1 & 1 & 1 & 1 & 0 & 1 & 0 \\
\hline & Sept. 86 & 1 & NA & 1 & 1 & 0 & 1 & 0 \\
\hline & April 89 & 1 & NA & 1 & 1 & 0 & 1 & 0 \\
\hline & Feb. 90 & 0 & NA & 1 & 1 & 1 & 1 & 1 \\
\hline \multirow[t]{3}{*}{ Bolivia } & Nov. 82 & 0 & 1 & 1 & NA & 0 & 1 & 1 \\
\hline & Nov. 83 & 0 & 1 & 1 & 0 & 0 & 1 & 1 \\
\hline & Sept. 85 & 0 & 0 & 1 & 1 & 1 & 1 & 1 \\
\hline \multirow[t]{5}{*}{ Brazil } & Feb. 83 & 0 & 0 & NA & NA & 0 & 1 & 1 \\
\hline & Nov. 86 & 1 & 1 & 1 & 1 & 1 & 1 & 0 \\
\hline & July 89 & 1 & 1 & 1 & 1 & 1 & 1 & 1 \\
\hline & Nov. 90 & 1 & 1 & 1 & 1 & 0 & 1 & 1 \\
\hline & Oct. 91 & 1 & 0 & 1 & 1 & 0 & 0 & 1 \\
\hline \multirow[t]{7}{*}{ Chile } & Dec. 71 & 1 & 1 & NA & NA & NA & 1 & NA \\
\hline & Aug. 72 & 1 & 1 & NA & NA & 1 & 1 & NA \\
\hline & Oct. 73 & 1 & 1 & NA & NA & 1 & 1 & 1 \\
\hline & Dec. 74 & 0 & 0 & NA & NA & 1 & 1 & 1 \\
\hline & Jan. 76 & 1 & 1 & NA & NA & 0 & 1 & 1 \\
\hline & Aug. 82 & 1 & 1 & 1 & 1 & 0 & 0 & 0 \\
\hline & Sept. 84 & 0 & 1 & 1 & 1 & 1 & 0 & 1 \\
\hline \multirow{2}{*}{ Colombia } & March 83 & 1 & 1 & 1 & NA & 0 & NA & 1 \\
\hline & Feb. 85 & 1 & 1 & 1 & NA & NA & 1 & 1 \\
\hline \multirow[t]{4}{*}{ Denmark } & May 71 & 1 & NA & NA & NA & 1 & NA & 1 \\
\hline & June 73 & 1 & 0 & NA & NA & 1 & 0 & 0 \\
\hline & Nov. 79 & 1 & 0 & NA & NA & 0 & 0 & 1 \\
\hline & Aug. 93 & 1 & 0 & 1 & 1 & 1 & 1 & 0 \\
\hline \multirow[t]{4}{*}{ Finland } & June 73 & 0 & 0 & NA & NA & 1 & 1 & 0 \\
\hline & Oct. 82 & 1 & 0 & NA & NA & 0 & 1 & 0 \\
\hline & Nov. 91 & 1 & 0 & 1 & 0 & 0 & 1 & 1 \\
\hline & Sept. 92 & 1 & 1 & 1 & 0 & 0 & 1 & 1 \\
\hline \multirow[t]{3}{*}{ Indonesia } & Nov. 78 & 1 & 1 & 1 & NA & 0 & 0 & 1 \\
\hline & April 83 & 1 & 1 & 0 & NA & 1 & 1 & 1 \\
\hline & Sept. 86 & 1 & 1 & 1 & 1 & 0 & 0 & 0 \\
\hline \multirow[t]{4}{*}{ Israel } & Nov. 74 & 1 & 1 & NA & NA & 1 & 1 & 1 \\
\hline & Nov. 77 & 1 & 1 & NA & NA & 0 & 1 & 0 \\
\hline & Oct. 83 & 0 & 0 & NA & NA & 0 & 0 & 0 \\
\hline & July 84 & 0 & 0 & NA & NA & 1 & 0 & 0 \\
\hline Malaysia & July 75 & 1 & 0 & NA & NA & 0 & 1 & 1 \\
\hline \multirow[t]{4}{*}{ Mexico } & Sept. 76 & 1 & 1 & NA & NA & 0 & 1 & 0 \\
\hline & Feb. 82 & 0 & 0 & 0 & 0 & 0 & 0 & 0 \\
\hline & Dec. 82 & 0 & 1 & 0 & 0 & 1 & 1 & 1 \\
\hline & Dec. 94 & 0 & 1 & 1 & 1 & 1 & 1 & 0 \\
\hline \multirow[t]{4}{*}{ Norway } & June 73 & 1 & 0 & NA & NA & 0 & 0 & 0 \\
\hline & Feb. 78 & 1 & 1 & NA & NA & 1 & 1 & 0 \\
\hline & May 86 & 1 & 1 & NA & NA & 0 & 1 & 0 \\
\hline & Dec. 92 & 1 & 0 & NA & 1 & 0 & 1 & 1 \\
\hline \multirow[t]{2}{*}{ Peru } & June 76 & 1 & 0 & NA & NA & 1 & 1 & 0 \\
\hline & Oct. 87 & 1 & 1 & NA & NA & 0 & 1 & 0 \\
\hline \multirow[t]{3}{*}{ Philippines } & Feb. 70 & NA & NA & NA & NA & NA & NA & NA \\
\hline & Oct. 83 & 1 & 1 & 1 & 0 & 0 & 1 & NA \\
\hline & June 84 & 1 & 1 & 1 & 1 & NA & 1 & NA \\
\hline
\end{tabular}


TABLE A1-Continued

\begin{tabular}{|c|c|c|c|c|c|c|c|c|c|}
\hline $\begin{array}{c}\text { Exports } \\
(8)\end{array}$ & $\begin{array}{c}\text { Imports } \\
\text { (9) }\end{array}$ & $\begin{array}{c}\text { Terms of } \\
\text { trade } \\
(10)\end{array}$ & $\begin{array}{l}\text { Real } \\
\text { exchange } \\
\text { rate } \\
(11)\end{array}$ & $\begin{array}{c}\text { Reserves } \\
(12)\end{array}$ & $\begin{array}{c}\text { Real } \\
\text { interest-rate } \\
\text { differential } \\
(13) \\
\end{array}$ & $\begin{array}{c}\text { Output } \\
\text { (14) }\end{array}$ & $\begin{array}{c}\text { Stock } \\
\text { prices } \\
(15) \\
\end{array}$ & $\begin{array}{c}\text { Deficit/ } \\
\text { GDP } \\
(16)\end{array}$ & $\begin{array}{c}\text { Total } \\
\text { number of } \\
\text { signals }^{\mathrm{b}} \\
(17)\end{array}$ \\
\hline NA & NA & NA & NA & NA & NA & NA & NA & NA & 100 \\
\hline 1 & 1 & 1 & 1 & 1 & NA & NA & NA & NA & 80 \\
\hline 1 & 1 & 0 & 1 & 0 & 1 & NA & 0 & NA & 54 \\
\hline 1 & 1 & NA & 1 & 1 & 1 & 1 & 1 & 0 & 80 \\
\hline 1 & 0 & 1 & 0 & 0 & 1 & 1 & 1 & 0 & 60 \\
\hline 1 & 0 & 0 & 0 & 1 & 1 & 0 & 0 & 0 & 47 \\
\hline 1 & 0 & 0 & 0 & 1 & 1 & 1 & 0 & 1 & 67 \\
\hline 0 & 1 & 0 & 1 & 1 & 1 & 0 & NA & NA & 62 \\
\hline 1 & 1 & 0 & 1 & 1 & 1 & 1 & NA & NA & 71 \\
\hline 1 & 1 & NA & 1 & 1 & 1 & 0 & NA & NA & 77 \\
\hline 1 & 0 & 1 & 0 & 1 & NA & NA & 0 & 0 & 42 \\
\hline 1 & 0 & 1 & 0 & 1 & 1 & NA & 0 & 0 & 67 \\
\hline 1 & 0 & 1 & 0 & 1 & 1 & 1 & 1 & 0 & 81 \\
\hline 1 & 0 & 1 & 1 & 1 & 1 & 1 & 1 & 0 & 81 \\
\hline 1 & 0 & 1 & 1 & 1 & 1 & 1 & 1 & 1 & 75 \\
\hline 1 & 1 & 1 & NA & 1 & NA & NA & NA & 0 & 88 \\
\hline 1 & 1 & 1 & 0 & 1 & NA & NA & NA & 0 & 80 \\
\hline 1 & 1 & 0 & 1 & 1 & NA & 1 & NA & 0 & 83 \\
\hline 1 & 1 & 1 & 1 & 1 & NA & 1 & NA & 0 & 75 \\
\hline 1 & 1 & 1 & 0 & 1 & NA & 1 & NA & 0 & 75 \\
\hline 1 & 1 & 1 & 1 & 0 & 1 & 1 & 1 & 1 & 75 \\
\hline 1 & 0 & 1 & 0 & 1 & 1 & 1 & 1 & 0 & 69 \\
\hline 1 & 1 & 1 & 1 & 1 & NA & 1 & 1 & 0 & 85 \\
\hline 1 & 0 & 0 & 1 & 1 & 1 & 1 & 1 & 0 & 79 \\
\hline NA & NA & NA & NA & NA & NA & NA & 1 & 0 & 80 \\
\hline 0 & 1 & NA & 0 & 0 & NA & 0 & 0 & 1 & 33 \\
\hline 0 & 1 & 1 & 1 & 0 & NA & 1 & 0 & 0 & 46 \\
\hline 1 & 0 & NA & 0 & 1 & 1 & 1 & 1 & 0 & 67 \\
\hline 0 & 0 & NA & 0 & 1 & NA & 0 & 0 & NA & 27 \\
\hline 1 & 0 & NA & 0 & 1 & NA & 1 & 0 & 0 & 42 \\
\hline 1 & 0 & 1 & 1 & 1 & 1 & 1 & 1 & 1 & 75 \\
\hline 1 & 0 & 1 & 1 & 1 & 1 & 1 & 1 & 1 & 81 \\
\hline 1 & 1 & 1 & 0 & 0 & 1 & 0 & NA & 0 & 57 \\
\hline 1 & 1 & NA & 1 & 1 & 0 & 1 & NA & 0 & 77 \\
\hline 1 & 0 & 1 & 1 & 0 & 1 & 1 & NA & 1 & 67 \\
\hline 1 & 1 & 1 & 1 & 1 & NA & 1 & NA & 0 & 92 \\
\hline 0 & 0 & 0 & 1 & 1 & NA & 1 & NA & 0 & 50 \\
\hline 1 & 0 & 0 & 0 & 0 & NA & 1 & NA & 0 & 17 \\
\hline 1 & 0 & 0 & 0 & 0 & NA & 1 & 1 & 0 & 31 \\
\hline 1 & 1 & 1 & 0 & 0 & NA & 1 & NA & 0 & 58 \\
\hline 1 & 1 & 0 & 0 & 0 & NA & 0 & NA & 0 & 42 \\
\hline 1 & 1 & 0 & 1 & 0 & 0 & 0 & 1 & 0 & 25 \\
\hline 1 & 1 & 1 & 1 & 1 & 0 & 1 & 1 & 0 & 69 \\
\hline 0 & 0 & 1 & 1 & 1 & 1 & 0 & 0 & NA & 60 \\
\hline 0 & 1 & NA & 0 & 0 & NA & 1 & 1 & 0 & 33 \\
\hline 1 & 1 & 1 & 1 & 1 & NA & 1 & 1 & 0 & 85 \\
\hline 1 & 1 & 1 & 0 & 0 & NA & 1 & 0 & 0 & 54 \\
\hline 1 & 0 & 1 & 0 & 1 & 1 & 1 & 1 & 1 & 73 \\
\hline 1 & 1 & NA & 1 & 1 & NA & NA & NA & 1 & 80 \\
\hline 1 & 1 & 1 & 0 & 1 & NA & 0 & NA & 0 & 58 \\
\hline NA & NA & NA & 1 & NA & NA & NA & NA & NA & 100 \\
\hline 1 & 0 & 1 & 1 & 1 & 0 & NA & 0 & 0 & 50 \\
\hline 1 & 0 & 1 & 1 & 1 & 0 & NA & 1 & 0 & 71 \\
\hline
\end{tabular}


TABLE A1-Continued

\begin{tabular}{|c|c|c|c|c|c|c|c|c|}
\hline Country & Crisis & $\begin{array}{c}\mathrm{M} 2 \\
\text { multiplier } \\
(1)\end{array}$ & $\begin{array}{c}\text { Domestic } \\
\text { credit/GDP } \\
(2)\end{array}$ & $\begin{array}{l}\text { Real } \\
\text { interest } \\
\text { rate } \\
(3) \\
\end{array}$ & $\begin{array}{l}\text { Lending- } \\
\text { deposit } \\
\text { rate ratio } \\
\text { (4) }\end{array}$ & $\begin{array}{c}\text { Excess } \\
\text { M1 } \\
\text { balances } \\
(5) \\
\end{array}$ & $\begin{array}{c}\mathrm{M} 2 / \\
\text { reserves } \\
(6)\end{array}$ & $\begin{array}{c}\text { Bank } \\
\text { deposits } \\
(7)\end{array}$ \\
\hline \multirow[t]{6}{*}{ Spain } & Feb. 86 & NA & NA & 1 & 1 & NA & NA & 1 \\
\hline & Feb. 76 & 1 & 1 & NA & NA & 1 & 1 & 1 \\
\hline & July 77 & 0 & 1 & NA & NA & 0 & 1 & 1 \\
\hline & Dec. 82 & 0 & 1 & 1 & NA & 0 & 1 & 0 \\
\hline & Sept. 92 & 1 & 0 & 1 & 0 & 0 & 0 & 0 \\
\hline & May 93 & 1 & 0 & 1 & 1 & 0 & 1 & 0 \\
\hline \multirow[t]{4}{*}{ Sweden } & Aug. 77 & 1 & 0 & 0 & 1 & NA & 1 & 1 \\
\hline & Sept. 81 & 1 & 1 & 0 & 0 & NA & 1 & 0 \\
\hline & Oct. 82 & 1 & 1 & 1 & 0 & NA & 1 & 0 \\
\hline & Nov. 92 & 1 & 0 & 1 & 1 & NA & 1 & 1 \\
\hline \multirow[t]{3}{*}{ Thailand } & Nov. 78 & 1 & 0 & 1 & NA & 0 & 0 & 0 \\
\hline & July 81 & 1 & 0 & 1 & NA & 0 & 1 & 1 \\
\hline & Nov. 84 & 1 & 1 & 1 & NA & 0 & 1 & 0 \\
\hline \multirow[t]{3}{*}{ Turkey } & Aug. 70 & NA & NA & NA & NA & NA & NA & NA \\
\hline & Jan. 80 & 0 & NA & NA & NA & NA & 1 & 1 \\
\hline & March 94 & 1 & 1 & 1 & 1 & 0 & 1 & 1 \\
\hline \multirow[t]{2}{*}{ Uruguay } & Dec. 71 & NA & 1 & NA & NA & 1 & 1 & NA \\
\hline & Oct. 82 & 1 & 1 & 1 & NA & 0 & 1 & 0 \\
\hline \multirow[t]{5}{*}{ Venezuela } & Feb. 84 & 1 & 1 & NA & NA & 0 & 1 & 0 \\
\hline & Dec. 86 & 1 & 0 & 1 & 1 & 1 & 1 & 0 \\
\hline & March 89 & 1 & 0 & 1 & 0 & 0 & 1 & 1 \\
\hline & May 94 & 1 & 1 & 1 & 1 & 0 & 1 & 1 \\
\hline & Dec. 95 & 1 & 1 & 1 & 1 & 0 & 1 & 1 \\
\hline \multicolumn{9}{|c|}{ OUT-OF-SAMPLE CRISES } \\
\hline Indonesia & Aug. 97 & 0 & NA & 1 & 0 & 0 & 0 & 0 \\
\hline Malaysia & Aug. 97 & NA & NA & 1 & NA & 1 & 1 & NA \\
\hline Philippines & July 97 & 1 & 1 & 1 & 1 & 1 & 0 & 0 \\
\hline Thailand & July 97 & 0 & NA & NA & NA & 0 & 1 & 1 \\
\hline \multicolumn{9}{|c|}{ SUMMARY STATISTICS } \\
\hline \multicolumn{2}{|c|}{ Percent of crises called ${ }^{\mathrm{c}}$} & 76 & 61 & 89 & 71 & 37 & 81 & 51 \\
\hline \multirow{2}{*}{\multicolumn{2}{|c|}{$\begin{array}{l}\text { Percent called before } \mathrm{FL}^{\mathrm{d}} \\
\text { Percent called after } \mathrm{FL}^{\mathrm{d}}\end{array}$}} & 74 & 56 & 78 & 50 & 52 & 74 & 44 \\
\hline & & 77 & 65 & 91 & 73 & 26 & 86 & 56 \\
\hline \multicolumn{2}{|c|}{ Noise-to-signal ratio ${ }^{\mathrm{e}}$} & 0.67 & 0.64 & 0.75 & 1.52 & 0.56 & 0.52 & 0.67 \\
\hline
\end{tabular}

multitude of weak and deteriorating economic fundamentals suggesting that it would be difficult to characterize them as self-fulfilling crises.

During much of 1997 and 1998, the financial press has frequently stressed that the crises in Asia are a new breed, as they supposedly occurred against a backdrop of immaculate fiscal and economic fundamentals. Yet our analysis of earlier episodes reveals that many of the features and antecedents of the crises in Asia were common to a substantial number of crisis episodes in Latin America, Europe, and elsewhere. Consider an economy that had successfully stabilized inflation, enjoyed an economic boom, 
TABLE A1-Continued

\begin{tabular}{|c|c|c|c|c|c|c|c|c|c|}
\hline $\begin{array}{c}\text { Exports } \\
(8) \\
\end{array}$ & $\begin{array}{c}\text { Imports } \\
(9)\end{array}$ & $\begin{array}{c}\text { Terms of } \\
\text { trade } \\
(10)\end{array}$ & $\begin{array}{l}\text { Real } \\
\text { exchange } \\
\text { rate } \\
(11)\end{array}$ & $\begin{array}{c}\text { Reserves } \\
(12)\end{array}$ & $\begin{array}{c}\text { Real } \\
\text { interest-rate } \\
\text { differential } \\
\text { (13) }\end{array}$ & $\begin{array}{c}\text { Output } \\
(14)\end{array}$ & $\begin{array}{c}\text { Stock } \\
\text { prices } \\
(15)\end{array}$ & $\begin{array}{l}\text { Deficit/ } \\
\text { GDP } \\
(16)\end{array}$ & $\begin{array}{l}\text { Total } \\
\text { number of } \\
\text { signals } \\
\text { (17) }\end{array}$ \\
\hline 1 & 0 & 1 & 1 & 1 & 1 & NA & 1 & 0 & 82 \\
\hline 1 & 1 & 1 & 0 & 0 & NA & 1 & 1 & 1 & 85 \\
\hline 1 & 1 & 1 & 0 & 1 & NA & 1 & 1 & 1 & 77 \\
\hline 1 & 0 & 1 & 0 & 1 & 1 & 1 & 1 & 0 & 60 \\
\hline 0 & 0 & 0 & 1 & 0 & 1 & 1 & 1 & 1 & 44 \\
\hline 1 & 0 & 0 & 1 & 1 & 1 & 1 & 1 & 0 & 63 \\
\hline 1 & 1 & 1 & 1 & 1 & 0 & 1 & 1 & 0 & 73 \\
\hline 1 & 1 & 1 & 1 & 1 & 1 & 1 & 0 & 0 & 67 \\
\hline 1 & 0 & 1 & 1 & 1 & 1 & 1 & 0 & 0 & 67 \\
\hline 1 & 0 & 1 & 1 & 1 & 1 & 1 & 1 & 1 & 87 \\
\hline 1 & 0 & 1 & 0 & 0 & 1 & NA & NA & 1 & 46 \\
\hline 1 & 1 & 1 & 1 & 1 & 1 & NA & 1 & 1 & 86 \\
\hline 1 & 1 & 1 & 1 & 1 & 1 & NA & 0 & 0 & 71 \\
\hline NA & NA & NA & NA & NA & NA & NA & NA & NA & NA \\
\hline 1 & 1 & NA & 1 & 0 & NA & NA & NA & 1 & 78 \\
\hline 0 & 0 & 0 & 1 & 1 & 1 & 0 & 0 & 0 & 56 \\
\hline 1 & NA & NA & NA & 1 & NA & NA & NA & 0 & 83 \\
\hline 1 & 1 & 1 & 1 & 1 & 1 & 1 & NA & 0 & 79 \\
\hline 1 & 0 & 1 & 1 & 1 & NA & 1 & 0 & 0 & 62 \\
\hline 1 & 0 & 1 & 0 & 1 & 1 & 0 & 0 & 1 & 63 \\
\hline 0 & 1 & 1 & 0 & 1 & 1 & 0 & 1 & 1 & 63 \\
\hline 1 & 0 & 1 & 0 & 1 & 1 & 0 & 1 & 0 & 69 \\
\hline 0 & 1 & 1 & 1 & 1 & 1 & 0 & 1 & 0 & 75 \\
\hline \multicolumn{10}{|c|}{ OUT-OF-SAMPLE CRISES } \\
\hline 0 & 0 & NA & NA & 0 & 1 & 1 & 0 & NA & 25 \\
\hline 0 & 0 & NA & 1 & 1 & 1 & 0 & 0 & NA & 60 \\
\hline 0 & 1 & NA & 1 & 0 & 1 & NA & 0 & NA & 62 \\
\hline 1 & 0 & NA & 1 & 1 & NA & 1 & 1 & NA & 70 \\
\hline \multicolumn{10}{|c|}{ SUMMARY STATISTICS } \\
\hline 85 & 52 & 75 & 59 & 75 & 86 & 74 & 64 & 27 & \\
\hline 78 & 73 & 73 & 58 & 70 & 78 & 68 & 54 & 21 & \\
\hline 89 & 40 & 77 & 60 & 78 & 89 & 76 & 68 & 31 & \\
\hline 0.40 & 1.10 & 0.70 & 0.14 & 0.55 & 0.90 & 0.46 & 0.38 & 0.49 & \\
\hline
\end{tabular}

${ }^{a}$ A 1 indicates that there was at least one signal in the 24 months preceding a crisis. NA indicates that some or all of the data were missing for the 24-month period.

${ }^{\mathrm{b}}$ Number of variables signalling a crisis as a proportion of the number of indicators for which data are available (in percent).

${ }^{\mathrm{c}}$ Number of crises accurately called divided by the number of crises for which data are available for that indicator. For example, for the M2 multiplier, the indicator correctly identified crises 76 percent of the time (54 out of 71).

${ }^{\mathrm{d}}$ FL: Financial liberalization.

e The noise-to-signal ratio is the number of bad signals as a proportion of the number of months outside the crisis window divided by the number of good signals as a proportion of the number of months in the crisis window.

and was running fiscal surpluses. However, this economy had liberalized its capital account and its domestic financial sector amidst an environment of weak regulation and poor banking supervision. Banking-sector problems emerged and intensified, eventually undermining the ability of the central bank to maintain its exchange-rate committment. While this profile fits Asia rather well, this was Díaz-Alejandro's description of the antecedents to the fierce Chilean crisis of 1982. At the roots of the meltdown of the Thai baht, Korean won, and Indonesian rupiah lay systemic banking problems. Thus, it would appear that we can only consider these 
TABle A2-Anatomy of BANKING CRISES ${ }^{\mathrm{a}}$

\begin{tabular}{|c|c|c|c|c|c|c|c|c|}
\hline Country & Crisis & $\begin{array}{c}\text { M2 } \\
\text { multiplier } \\
\quad(1)\end{array}$ & $\begin{array}{c}\text { Domestic } \\
\text { credit/GDP } \\
(2)\end{array}$ & $\begin{array}{l}\text { Real } \\
\text { interest } \\
\text { rate } \\
(3) \\
\end{array}$ & $\begin{array}{l}\text { Lending- } \\
\text { deposit } \\
\text { rate ratio } \\
\text { (4) }\end{array}$ & $\begin{array}{c}\text { Excess } \\
\text { M1 } \\
\text { balances } \\
(5) \\
\end{array}$ & $\begin{array}{c}\mathrm{M} 2 / \\
\text { reserves } \\
(6)\end{array}$ & $\begin{array}{c}\text { Bank } \\
\text { deposits } \\
(7)\end{array}$ \\
\hline \multirow[t]{3}{*}{ Argentina } & March 80 & 1 & 0 & 1 & 0 & 0 & 1 & 0 \\
\hline & May 85 & 1 & NA & 1 & 1 & 0 & 1 & 0 \\
\hline & Dec. 94 & NA & NA & 1 & 1 & NA & NA & NA \\
\hline Bolivia & Oct. 87 & 1 & 1 & 1 & 0 & NA & 1 & 0 \\
\hline \multirow[t]{2}{*}{ Brazil } & Nov. 85 & 1 & 1 & 1 & 1 & 1 & 1 & 0 \\
\hline & Dec. 94 & NA & NA & 1 & 1 & NA & 1 & 1 \\
\hline Chile & Sept. 81 & 1 & 1 & 1 & 0 & 1 & 0 & 0 \\
\hline Colombia & July 82 & 1 & NA & 1 & NA & 0 & NA & 1 \\
\hline Denmark & March 87 & NA & 1 & 1 & 0 & 0 & 1 & 1 \\
\hline Finland & Sept. 91 & 1 & 1 & 1 & 0 & 0 & 1 & 1 \\
\hline Indonesia & Nov. 92 & 1 & 0 & 1 & 1 & 0 & 0 & 1 \\
\hline Israel & Oct. 83 & 0 & 0 & 1 & NA & 1 & 1 & 1 \\
\hline Malaysia & July 85 & 1 & 0 & 1 & 0 & 0 & 1 & 1 \\
\hline \multirow[t]{2}{*}{ Mexico } & Sept. 82 & 0 & 1 & 1 & NA & 1 & 1 & 1 \\
\hline & Oct. 92 & 0 & 0 & 1 & 1 & 1 & 0 & 0 \\
\hline Norway & Nov. 88 & 1 & 1 & 1 & NA & 0 & 1 & 1 \\
\hline Peru & March 83 & 0 & 1 & NA & NA & 0 & 0 & 1 \\
\hline Philippines & Jan. 81 & 1 & 0 & NA & NA & 0 & 1 & 1 \\
\hline Spain & Nov. 78 & 0 & 0 & NA & NA & 0 & 0 & 1 \\
\hline Sweden & Nov. 91 & 1 & 0 & 1 & 1 & NA & 1 & 1 \\
\hline \multirow[t]{2}{*}{ Thailand } & March 79 & 0 & 0 & 1 & NA & 0 & 1 & 1 \\
\hline & Oct. 83 & 1 & 1 & 1 & NA & 0 & 1 & 0 \\
\hline Turkey & Jan. 91 & 1 & 0 & 1 & 1 & 1 & 0 & 1 \\
\hline \multirow[t]{2}{*}{ Uruguay } & March 71 & NA & 1 & NA & NA & 1 & 1 & NA \\
\hline & March 81 & 1 & 0 & 1 & NA & 0 & 1 & 0 \\
\hline Venezuela & Oct. 93 & 1 & 1 & 1 & 1 & 0 & 1 & 1 \\
\hline \multicolumn{9}{|c|}{ OUT-OF-SAMPLE CRISES } \\
\hline Malaysia & Sept. 97 & NA & NA & 1 & NA & 1 & NA & NA \\
\hline Philippines & July 97 & NA & 1 & 1 & 1 & 1 & NA & NA \\
\hline Thailand & May 96 & NA & NA & 1 & NA & 1 & 1 & 1 \\
\hline \multicolumn{9}{|c|}{ SUMMARY STATISTICS } \\
\hline \multirow{2}{*}{\multicolumn{2}{|c|}{$\begin{array}{l}\text { Percent of crises called } \\
\text { Noise-to-signal ratio }^{\mathrm{d}}\end{array}$}} & 73 & 50 & 100 & 57 & 32 & 75 & 67 \\
\hline & & 0.50 & 0.59 & 0.45 & 1.93 & 0.82 & 0.71 & 1.03 \\
\hline
\end{tabular}

crises as a new breed if we ignore the numerous lessons history offers. Thus, among the lessons that emerge from this analysis is the obvious case for strong banking regulation and supervision to allow countries to sail smoothly through the perilous waters of financial liberalization. Yet, the Asian episodes of 1997-1998, like many of their earlier Latin American counter- parts, also remind us that capital inflows can on occasion be too much of a good thing.

The results presented in this paper are a first step in evaluating the complex linkages between currency and domestic financial crises. Analyzing how the authorities deal with the banking problems and how the problems affect exchange-rate expectations will help determine whether a bank- 
TABLE A2-Continued

\begin{tabular}{|c|c|c|c|c|c|c|c|c|c|}
\hline $\begin{array}{c}\text { Exports } \\
(8) \\
\end{array}$ & $\begin{array}{c}\text { Imports } \\
\text { (9) }\end{array}$ & $\begin{array}{c}\text { Terms of } \\
\text { trade } \\
(10)\end{array}$ & $\begin{array}{l}\text { Real } \\
\text { exchange } \\
\text { rate } \\
(11)\end{array}$ & $\begin{array}{c}\text { Reserves } \\
(12)\end{array}$ & $\begin{array}{c}\text { Real } \\
\text { interest-rate } \\
\text { differential } \\
\text { (13) }\end{array}$ & $\begin{array}{c}\text { Output } \\
\text { (14) }\end{array}$ & $\begin{array}{c}\text { Stock } \\
\text { prices } \\
(15)\end{array}$ & $\begin{array}{c}\text { Deficit/ } \\
\text { GDP } \\
(16)\end{array}$ & $\begin{array}{l}\text { Total } \\
\text { number of } \\
\text { signals }^{\text {b }} \\
(17)\end{array}$ \\
\hline 1 & 1 & 1 & 1 & 1 & 1 & NA & 0 & NA & 64 \\
\hline 1 & 0 & 1 & 0 & 1 & 1 & 1 & 1 & 0 & 67 \\
\hline NA & 1 & NA & 1 & 1 & 1 & 1 & NA & NA & 100 \\
\hline 1 & 1 & 1 & 0 & 1 & 1 & NA & NA & 1 & 77 \\
\hline 1 & 0 & 1 & 0 & 1 & 1 & NA & 0 & 0 & 67 \\
\hline NA & 1 & 1 & 1 & 1 & 1 & 1 & 1 & NA & 100 \\
\hline 1 & 1 & 1 & 1 & 1 & 1 & 1 & 1 & 1 & 81 \\
\hline 1 & 0 & 1 & 1 & 1 & 1 & 1 & 1 & 0 & 77 \\
\hline 0 & 1 & NA & 0 & 1 & 1 & 1 & 1 & 1 & 71 \\
\hline 1 & 0 & 1 & 1 & 1 & 1 & 1 & 1 & 1 & 81 \\
\hline 1 & 0 & 1 & 0 & 1 & 1 & 1 & 1 & 1 & 69 \\
\hline 1 & 0 & 0 & 0 & 1 & NA & 1 & 1 & 0 & 57 \\
\hline 1 & 0 & 1 & 1 & 1 & 1 & 1 & 1 & 0 & 69 \\
\hline 1 & 0 & 1 & 1 & 1 & NA & 1 & 1 & 1 & 86 \\
\hline 1 & 1 & 1 & 1 & 0 & 1 & 1 & 0 & NA & 60 \\
\hline 1 & 1 & 1 & 1 & 1 & 1 & 1 & 1 & 0 & 87 \\
\hline 1 & 0 & 1 & 0 & 1 & NA & 1 & NA & 0 & 50 \\
\hline 1 & 1 & 1 & 1 & 1 & NA & NA & 1 & 0 & 75 \\
\hline 0 & 1 & 1 & 1 & 0 & NA & 0 & 1 & 0 & 38 \\
\hline 1 & 1 & 1 & 1 & 1 & 1 & 1 & 1 & 1 & 93 \\
\hline 0 & 1 & 1 & 0 & 1 & 1 & NA & 1 & 0 & 57 \\
\hline 1 & 1 & 1 & 1 & 1 & 1 & NA & 0 & NA & 77 \\
\hline 1 & 1 & 1 & 0 & 1 & 1 & NA & 1 & 1 & 80 \\
\hline 1 & NA & NA & 0 & 1 & NA & NA & NA & 0 & 71 \\
\hline 1 & 1 & 1 & 1 & 1 & 1 & 1 & NA & 0 & 71 \\
\hline 1 & 0 & 1 & 0 & 1 & 1 & 0 & 1 & 1 & 75 \\
\hline \multicolumn{10}{|c|}{ OUT-OF-SAMPLE CRISES } \\
\hline NA & NA & NA & 1 & NA & 1 & NA & NA & NA & 100 \\
\hline NA & NA & NA & 1 & NA & 1 & NA & NA & NA & 100 \\
\hline 1 & NA & NA & 1 & 1 & NA & NA & 1 & NA & 100 \\
\hline \multicolumn{10}{|c|}{ SUMMARY STATISTICS } \\
\hline 88 & 60 & 96 & 58 & 92 & 100 & 89 & 81 & 43 & \\
\hline 0.61 & 1.60 & 0.79 & 0.28 & 0.71 & 0.52 & 0.48 & 0.28 & 0.44 & \\
\hline
\end{tabular}

a A 1 indicates that there was at least one signal in the 24-month window around the crisis. NA indicates that some or all of the data were missing for the 24-month period.

${ }^{\mathrm{b}}$ Number of variables signalling a crisis as a proportion of the number of indicators for which data are available (in percent).

${ }^{\mathrm{c}}$ Number of crises accurately called divided by the number of crises for which data are available for that indicator. For example, for the M2 multiplier, the indicator correctly identified crises 73 percent of the time (16 out of 22).

${ }^{d}$ The noise-to-signal ratio is the number of bad signals as a proportion of the number of months outside the crisis window divided by the number of good signals as a proportion of the number of months in the crisis window.

ing crises will lead to a balance-of-payments crisis. We have only considered macroeconomic data in our list of indicators, but data of the health of bank balance sheets would be a logical complement to the macro data. Future analysis could provide a more detailed evaluation of the univariate and multivariate signaling properties of various macroeconomic time series and composite indices along the lines of Diebold and Rudebusch (1989) and Stock and Watson (1989). Indeed, that would appear to be a logical first step in the design of an early-warning system designed to help detect when a crisis is coming.

While this paper has focused on the similarities and common patterns across crises, it would also be useful to investigate whether 
there is evidence of distinct regional patterns. Why is it that in some countries currency crises and banking crises are not associated with deep and protracted recessions, while in others, notably in Latin America, the aftermath is so severe? Lastly, events (such as a balance-ofpayments crises in a neighboring country) may also help assess whether a crisis is brewing in the home front; hence, the role of contagion effects may warrant further scrutiny.

\section{Data ApPENDix}

\section{Index of Currency Market Turbulence}

The index, $I$, is a weighted average of the rate of change of the exchange rate, $\Delta_{e} / e$, and of reserves, $\Delta_{R} / R$, with weights such that the two components of the index have equal sample volatilities.

$$
I=\frac{\Delta_{e}}{e}-\frac{\sigma_{e}}{\sigma_{R}} \cdot \frac{\Delta_{R}}{R}
$$

where $\sigma_{e}$ is the standard deviation of the rate of change of the exchange rate and $\sigma_{R}$ is the standard deviation of the rate of change of reserves. Since changes in the exchange rate enter with a positive weight and changes in reserves have a negative weight attached, readings of this index that were three standard deviations or more above the mean were cataloged as crises. For countries in the sample that had hyperinflation, the construction of the index was modified. While a 100-percent devaluation may be traumatic for a country with low-to-moderate inflation, a devaluation of that magnitude is commonplace during hyperinflations. A single index for the countries that had hyperinflation episodes would miss sizable devaluations and reserve losses in the moderate inflation periods, since the historic mean is distorted by the highinflation episode. To avoid this, we divided the sample according to whether inflation in the previous six months was higher than 150 percent and then constructed an index for each subsample. Our cataloging of crises for the countries coincides fairly highly with our chronology of currency market disruptions. Eichengreen et al. (1996b) also include interest rates in this index; however, our data on market-deter- mined interest rates on developing countries does not span the entire sample.

\section{The Indicators}

Sources: International Financial Statistics (IFS), International Monetary Fund (IMF), various issues; Emerging Market Indicators, International Finance Corporation (IFC), various issues; World Development Indicators, World Bank (WB), various issues. When data was missing from these sources, central-bank bulletins and other country-specific sources were used as supplements. Unless otherwise noted, we used 12-month percent changes.

1. M2 multiplier: The ratio of M2 (IFS lines 34 plus 35) to base money (IFS line 14).

2. Domestic credit/GDP: IFS line 52 divided by IFS line 64 to obtain domestic credit in real terms, which was then divided by IFS line 99b.p. (interpolated) to obtain the domestic credit/GDP ratio. Monthly real GDP was interpolated from annual data.

3. Real interest rate: Deposit rate (IFS line 60) deflated using consumer prices (IFS line 64). Monthly rates expressed in percentage points. In levels.

4. Lending-deposit rate ratio: IFS line $60 \mathrm{p}$ divided by IFS line 60 was used in lieu of differential to ameliorate the distortions caused by the large percentage point spreads observed during high inflation. In levels.

5. Excess M1 balances: M1 (IFS line 34) deflated by consumer prices (IFS line 64) less an estimated demand for money. The demand for real balances is determined by real GDP (interpolated IFS line 99b.p), domestic consumer price inflation, and a time trend. Domestic inflation was used in lieu of nominal interest rates, as market-determined interest rates were not available during the entire sample for a number of countries; the time trend (which can enter log-linearly, linearly, or exponentially) is motivated by its role as a proxy for financial innovation and/or currency substitution. In levels.

6. M2/reserves: IFS lines 34 plus 35 converted into dollars (using IFS line ae) divided by IFS line 1L.d.

7. Bank deposits: IFS line 24 plus 25 deflated by consumer prices (IFS line 64).

8. Exports: IFS line 70. 
9. Imports: IFS line 71.

10. Terms of trade: The unit value of exports (IFS line 74) over the unit value of imports (IFS line 75). For those developing countries where import unit values (or import price indices) were not available, an index of prices of manufactured exports from industrial countries to developing countries was used.

11. The real exchange rate: The real exchange-rate index is derived from a nominal exchange-rate index, adjusted for relative consumer prices (IFS line 64). The measure is defined as the relative price of foreign goods (in domestic currency) to the price of domestic goods. The nominal exchange-rate index is a weighted average of the exchange rates of the 19 OECD countries with weights equal to the country trade shares with the OECD countries. Since not all real appreciations reflect disequilibrium phenomena, we focus on deviations of the real exchange rate from trend. The trend was specified as, alternatively, log, linear, and exponential; the best fit among these was selected on a country-by-country basis. In levels.

12. Reserves: IFS line 1L.d.

13. Real interest-rate differential: Interest rates in the domestic economy are compared with interest rates in the United States (Germany) if the domestic central bank pegs the currency to the dollar (deutsche mark). The interest-rate differential is constructed as the difference between real rates for the domestic and foreign countries. Real rates are deposit rates (IFS line 60) deflated using consumer prices (IFS line 64).

14. Output: For most countries, the measure of output used is industrial production (IFS line 66). However, for some countries, (the commodity exporters) an index of out-put of primary commodities is used (IFS lines 66aa) if industrial production is not available.

15. Stock returns: IFC global indices are used for all emerging markets; for industrial countries the quotes from the main boards are used. All stock prices are in US dollars.

16. GDP: Consolidated public-sector deficit as a share of GDP (World Development Indicators, various issues).

\section{REFERENCES}

American Banker. Various issues.

Blanco, Herminio and Garber, Peter M. "Recurrent
Devaluations and Speculative Attacks on the Mexican Peso." Journal of Political Economy, February 1986, 94 (1), pp. 148-66.

Calomiris, Charles W. and Gorton, Gary. "The Origins of Banking Panics: Models, Facts, and Bank Regulation," in R. Glenn Hubbard, ed., Financial markets and financial crises. Chicago: University of Chicago Press, 1991, pp. 109-73.

Calvo, Guillermo A. "Varieties of Capital-Market Crises." Mimeo, University of Maryland, 1995.

Calvo, Guillermo A.; Leiderman, Leonardo and Reinhart, Carmen M. "Capital Inflows and Real Exchange Rate Appreciation: The Role of External Factors." International Monetary Fund Staff Papers, March 1993, 40 (1), pp. 108-51.

Calvo, Guillermo A. and Mendoza, Enrique. "Petty Crime and Cruel Punishment: Lessons from the Mexican Debacle." American Economic Review, May 1996 (Papers and Proceedings), 86 (2), pp. 170-75.

Calvo, Sara and Reinhart, Carmen M. "Capital Flows to Latin America: Is There Evidence of Contagion Effects?" in Guillermo A. Calvo, Morris Goldstein, and Eduard Hochreiter, eds., Private capital flows to emerging markets. Washington, DC: Institute for International Economics, 1996, pp. 151-71.

Caprio, Gerald, Jr. and Klingebiel, Daniela. "Bank Insolvency: Bad Luck, Bad Policy, or Bad Banking?" in Michael Bruno and Boris Pleskovic, ed., Annual World Bank conference on development economics. Washington, DC: World Bank, 1996, pp. 79-104.

Díaz-Alejandro, Carlos F. "Good-Bye Financial Repression, Hello Financial Crash." Journal of Development Economics, February 1985, 19 (1-2), pp. 1-24.

Diebold, Francis and Rudebusch, Glen. "Scoring the Leading Indicators." Journal of Business, July 1989, 62 (3), pp. 369-91.

Dornbusch, Rudiger; Goldfajn, Ilan and Valdés, Rodrigo O. "Currency Crises and Collapses." Brookings Papers on Economic Activity, June 1995, (2), pp. 219-70.

Edwards, Sebastian. "Real Exchange Rates, Devaluation, and Adjustment: Exchange Rate Policy in Developing Countries." Cambridge, MA: MIT Press, 1989.

Eichengreen, Barry; Rose, Andrew K. and Wyplosz, Charles. "Contagious Currency Crises." Centre for Economic Policy Research (London) Discussion Paper No. 1453, August 1996a. 
. "Exchange Market Mayhem: The Antecedents and Aftermath of Speculative Attacks." Economic Policy, October 1996b, 21 (21), pp. 249-312.

Emerging Market Indicators. Washington, DC: International Finance Corporation, various issues.

Frankel, Jeffrey and Rose, Andrew K. "Exchange Rate Crises in Emerging Markets." Journal of International Economics, November 1996, 41 (3-4), pp. 351-68.

Galbis, Vicente. "High Real Interest Rates Under Financial Liberalization: Is There a Problem?." International Monetary Fund Working Paper No. WP/93/7, January 1993.

Goldfajn, Ilan and Valdés, Rodrigo O. "Balance-ofPayments Crises and Capital Flows: The Role of Liquidity." Mimeo, Massachusetts Institute of Technology, 1995.

Gorton, Gary. "Banking Panics and Business Cycles." Oxford Economic Papers, December 1988, 40 (4), pp. 751-81.

International Financial Statistics. Washington, DC: International Monetary Fund, various issues.

Kaminsky, Graciela L. and Leiderman, Leonardo. "High Real Interest Rates in the Aftermath of Disinflation: Is It a Lack of Credibility?" Journal of Development Economics, February 1998, 55 (1), pp. 191-214.

Kaminsky, Graciela L. and Reinhart, Carmen M. "The Twin Crises: The Causes of Banking and Balance-of-Payments Problems.' International Finance Discussion Paper No. 544, Board of Governors of the Federal Reserve System, March 1996.

Kindelberger, Charles. Manias, panics, and crashes. New York: Basic Books, 1978.

Krugman, Paul. "A Model of Balance-of-Payments Crises." Journal of Money, Credit, and Banking, August 1979, 11 (3), pp. 311-25.

McKinnon, Ronald I. and Pill, Huw. "Credible Liberalizations and International Capital Flows: The 'Overborrowing Syndrome'," in Takatoshi Ito and Anne O. Krueger, eds., Financial deregulation and integration in East Asia. Chicago: University of Chicago Press, 1996, pp. 7-42.

Miller, Victoria. "Central Bank Reactions to
Banking Crises in Fixed Exchange Rate Regimes." Mimeo, Université de Québec à Montréal, 1995.

Mishkin, Frederic S. "Understanding Financial Crises: A Developing Country Perspective," in Michael Bruno and Boris Pleskovic, eds., Annual World Bank conference on development economics. Washington DC: World Bank, 1996, pp. 29-62.

Mishra, Deepak. "Political Determinants of Currency Crises: Theory and Evidence." Mimeo, University of Maryland, 1997.

New York Times. Various issues.

Obstfeld, Maurice. "The Logic of Currency Crises." National Bureau of Economic Research (Cambridge, MA) Working Paper No. 4640, February 1994.

"Models of Currency Crises with Selffulfilling Features." European Economic Review, April 1996, 40 (1), pp. 1037-47.

Reinhart, Carmen M. and Reinhart, Vincent R. "Forecasting Turning Points in Canada." Mimeo, International Monetary Fund, 1996.

Reinhart, Carmen M. and Végh, Carlos A. "Do Exchange Rate-Based Inflation Stabilizations Sow the Seeds of Their Own Destruction?" Mimeo, International Monetary Fund, 1996.

Stock, James H. and Watson, Mark W. "New Indexes of Coincident and Leading Economic Indicators," in Olivier Jean Blanchard and Stanley Fischer, eds., NBER macroeconomics annual. Cambridge, MA: MIT Press, 1989, pp. 351-94.

Stoker, James. "Intermediation and the Business Cycle Under a Specie Standard: The Role of the Gold Standard in English Financial Crises, 1790-1850." Mimeo, University of Chicago, 1994.

Sundararajan, V. and Baliño, Tomas. "Issues in Recent Banking Crises," in V. Sundararajan and Tomas Baliño, eds., Banking crises: Cases and issues. Washington, DC: International Monetary Fund, 1991, pp. 1-57.

Velasco, Andres. "Financial Crises and Balance of Payments Crises: A Simple Model of the Southern Cone Experience." Journal of Development Economics, October 1987, 27 (1-2), pp. 263-83.

Wall Street Journal. Various issues.

World Development Indicators. Washington DC: World Bank, various issues. 